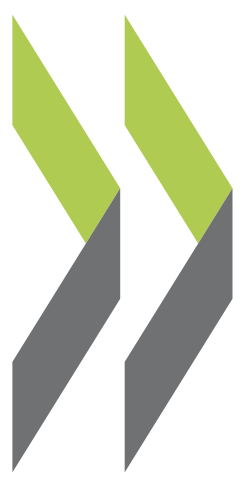

OECD Economics Department Working Papers No. 1067 Randall S. Jones 


\title{
Unclassified
}

ECO/WKP(2013)59

Organisation de Coopération et de Développement Économiques

Organisation for Economic Co-operation and Development

27-Jun-2013

ECONOMICS DEPARTMENT

English - Or. English

\section{EDUCATION REFORM IN KOREA}

ECONOMICS DEPARTMENT WORKING PAPERS No. 1067

\author{
By Randall S. Jones
}

All Economics Department Working Papers are available through OECD's Internet website at http://www.oecd.org/eco/Workingpapers

JT03342495

Complete document available on OLIS in its original format

This document and any map included herein are without prejudice to the status of or sovereignty over any territory, to the delimitation of international frontiers and boundaries and to the name of any territory, city or area. 


\section{ABSTRACT/ RÉSUMÉ}

\section{Education reform in Korea}

The rapid expansion of education in Korea is exceptional and has played a key role in its economic development. Sustaining Korea's growth potential in the face of demographic headwinds requires further improving the education system to boost productivity growth. One priority is to upgrade early childhood education and care (ECEC). Korea also needs to address the overemphasis on tertiary education, in part by improving vocational education, to reduce the mismatch problem that limits labour participation of youth. Tertiary education needs restructuring to improve quality. In addition, the large share of private spending in education increases the impact of socio-economic factors on educational outcomes. Education reforms are thus needed to promote inclusive growth, notably by: $i$ ) improving the access of low-income children to high-quality ECEC; ii) reducing reliance on private tutoring, notably at hagwons, by improving university admission procedures, expanding the quality and diversity of schools and upgrading vocational education; and iii) expanding loans to university students with repayment contingent on income after graduation.

This Working Paper relates to the 2012 OECD Economic Survey of Korea (www.oecd.org/eco/surveys/Korea).

JEL classification: I21, I22, I23, I24.

Keywords: Korea, Korean education, childcare, kindergarten, ECEC, pre-primary education, primary schools, secondary schools, vocational education, Meister schools, tertiary education, universities, hagwons, after-school tutoring, tuition fees, student loans

\section{La réforme de l'enseignement en Corée}

L'expansion rapide de l'enseignement en Corée est exceptionnelle et elle a joué un rôle clé dans son développement économique. Maintenir le potentiel de croissance de la Corée face à l'obstacle démographique nécessite la poursuite de l'amélioration du système éducatif dans l'optique de stimuler la croissance de la productivité. Une priorité est d'améliorer l'éducation et l'accueil des jeunes enfants (EAJE). La Corée doit aussi s'attaquer au problème de la survalorisation de l'enseignement supérieur, notamment sur le front de l'enseignement professionnel, et remédier ainsi à l'inadéquation entre l'offre et la demande de travail qui bride le taux d'activité des jeunes. L'enseignement supérieur doit être restructuré pour gagner en qualité. De plus, le pourcentage élevé des dépenses privées d'éducation accroît l'impact des facteurs socio-économiques sur les résultats des Coréens en termes d'instruction. Des réformes de l'éducation sont ainsi nécessaires pour promouvoir une croissance solidaire, en particulier : i) améliorer l'accès des enfants de familles défavorisées à des services d'EAJE de qualité ; ii) moins recourir aux cours de soutien privés, en particulier dans le cadre des hagwons, en faisant évoluer les procédures d'admission à l'université, en rehaussant la qualité et la diversité des écoles et en améliorant l'enseignement professionnel; et iii) accorder davantage de prêts aux étudiants dont le remboursement est fonction du revenu perçu après l'obtention du diplôme.

Ce Document de travail se rapporte à l'Étude économique de l'OCDE de la Corée, 2012 (www.oecd.org/eco/etudes/corée).

Classification JEL : I21, I22, I23, I24.

Mots clés : Corée, enseignement coréen, services de garde d'enfants, maternelle, EAJE, éducation préscolaire, école primaire, école secondaire, enseignement professionnel, écoles Meister, enseignement supérieur, hagwons, cours de soutien privés extrascolaires, droits d'inscription

Application for permission to reproduce or translate all, or part of, this material should be made to: Head of Publications Service, OECD, 2 rue André-Pascal, 75775 Paris Cedex 16, France. 


\section{TABLE OF CONTENTS}

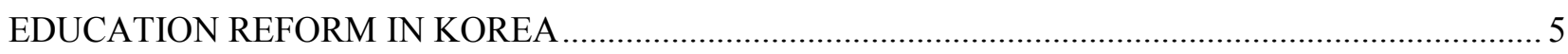

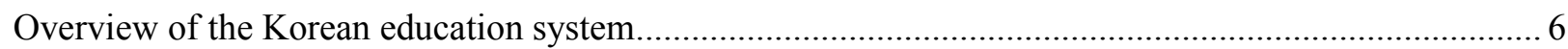

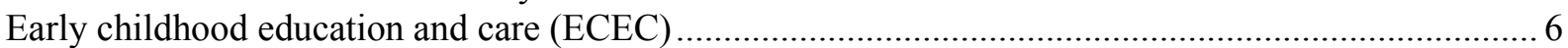

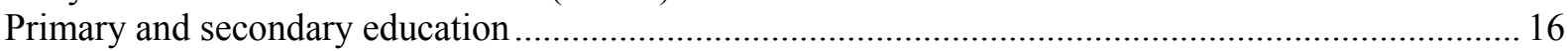

The shadow education system: the role of hagwons and other private tutoring institutions ................. 18

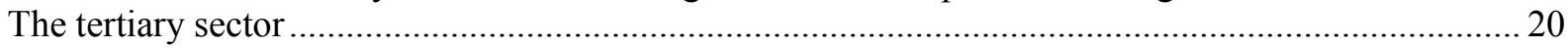

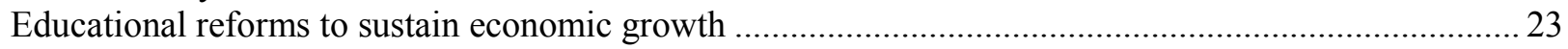

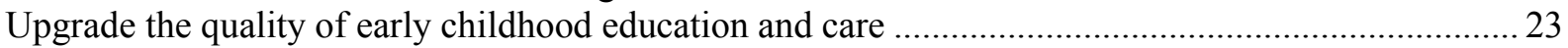

Improve the quality of primary and secondary schools through greater autonomy and diversity .........26

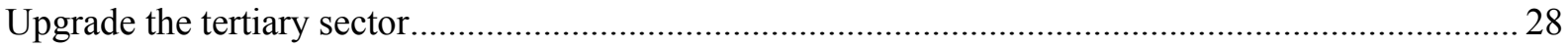

Improve vocational education to address the overemphasis on tertiary education................................ 31

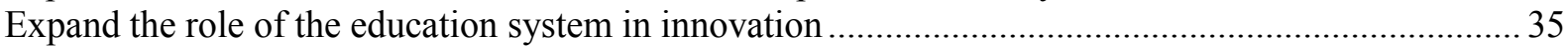

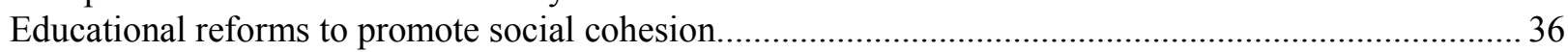

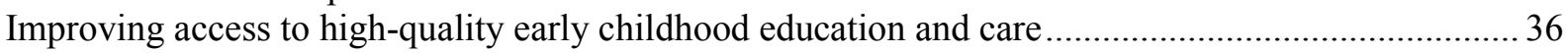

Improving access to high-quality early childhood education and care ................................................. 37

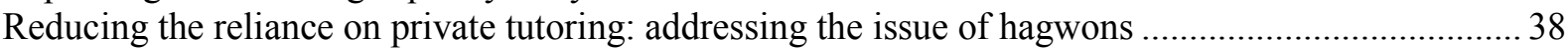

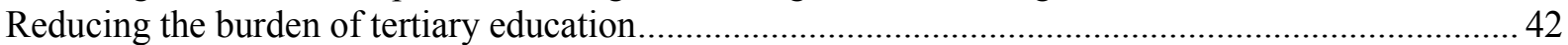

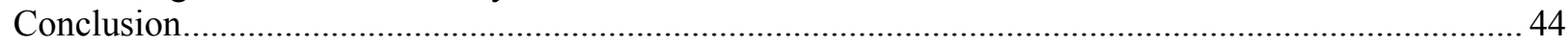

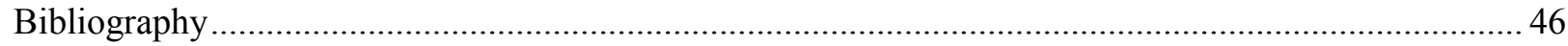

\section{Tables}

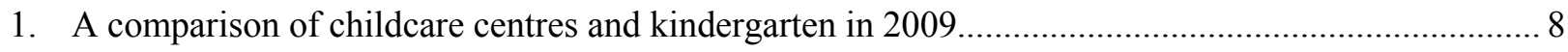

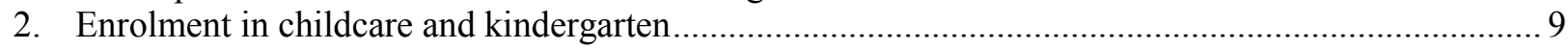

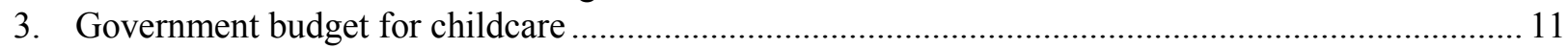

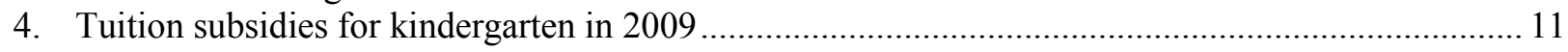

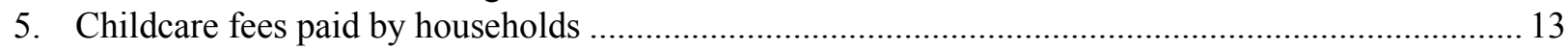

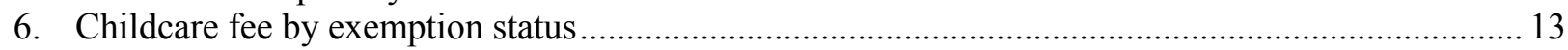

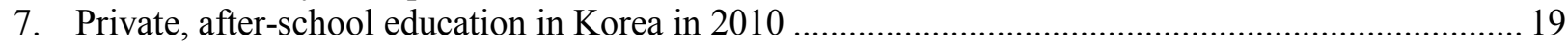

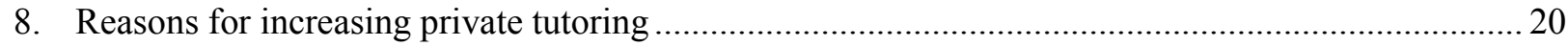

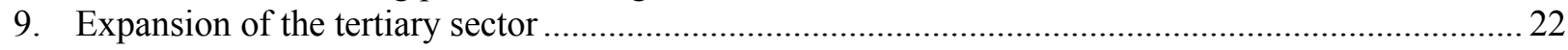

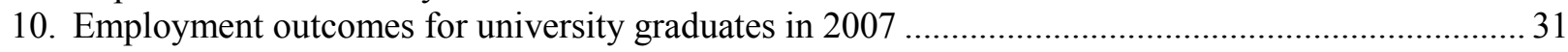

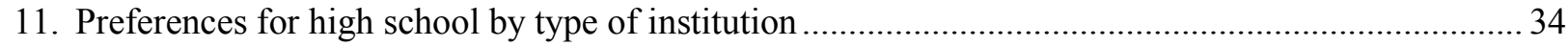

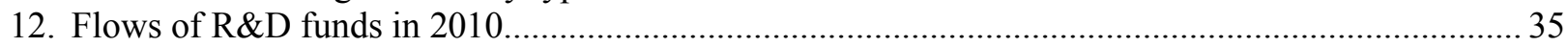

13. Participation and spending in private tutoring rises with academic performance ............................ 39

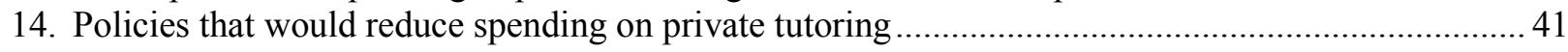

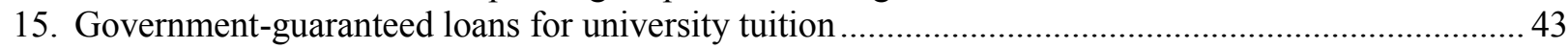

\section{Figures}

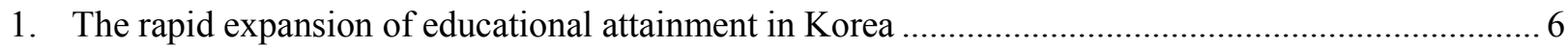

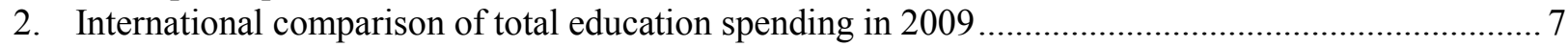

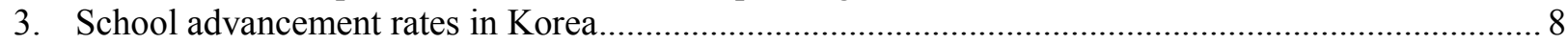

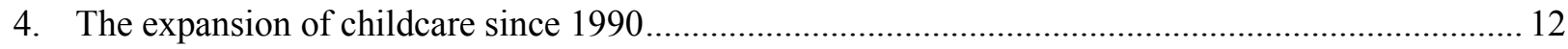




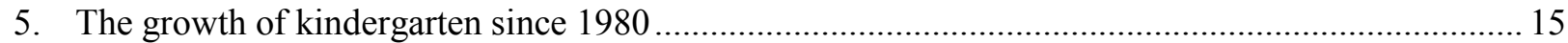

6. International comparison of student performance on the PISA test .............................................. 16

7. The percentage of students attending after-school lessons in Korea is exceptionally high ................ 19

8. Spending per student on pre-primary education is low in Korea.................................................24

9. Trends in the number of schools and teachers during the past decade ............................................2 26

10. The share of inactive youth with tertiary education is high in Korea ............................................. 32

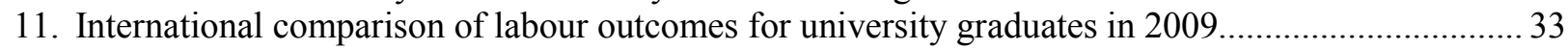

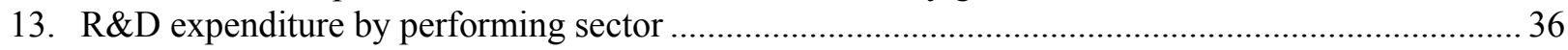

13. Households' share of spending on educational institutions is high in Korea ...................................... 37

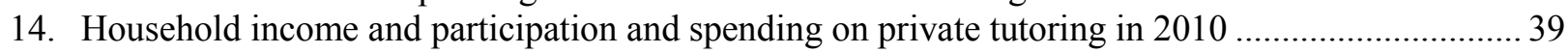

15. International comparison of university tuition fees .................................................................... 42

\section{Boxes}

Box 1. Cost and financing of early childhood education and care in Korea ......................................... 10

Box 2. Government policies to limit the role of hagwons and other forms of private tutoring ................ 21

Box 3. Summary of recommendations to reform Korea's education system .......................................... 45

The statistical data for Israel are supplied by and under the responsibility of the relevant Israeli authorities. The use of such data by the OECD is without prejudice to the status of the Golan Heights, East Jerusalem and Israeli settlements in the West Bank under the terms of international law. 
ECO/WKP(2013)59

\title{
EDUCATION REFORM IN KOREA
}

\begin{abstract}
By Randall S. Jones ${ }^{1}$
1. Education played a key role in Korea's transformation from one of the poorest countries in the world to a leading industrial nation by promoting the development of human resources and technological change. In 1945 , the literacy rate was $22 \%$ and less than $20 \%$ of children attended secondary school. Enrolment rates reached $90 \%$ for primary school in 1964, for middle school in 1979 and high school in 1993 (Sorensen, 1994). Each phase of investment in education fuelled economic growth. The development of primary education following the Korean War supplied the workers for the labour-intensive industries of the 1960s. The expansion of secondary education contributed to the development of capital-intensive industries in the 1970s and 1980s. ${ }^{2}$ In addition to the impact on output growth, the emphasis on providing universal access to primary and secondary schools promoted social mobility and income equality (Koh et al., 2010). Finally, the focus shifted to expanding tertiary education in the 1990s, laying the foundation for Korea's success in IT and the growth of a knowledge-based economy.
\end{abstract}

2. The exceptionally rapid development of education in Korea is illustrated by differences in the level of educational attainment for different age cohorts. The share of the population with at least a secondary education ranges from $98 \%$, the highest in the OECD area, for young adults (25 to 34 ) to only $43 \%$ for older adults (55 to 64) (Figure 1). Similarly, 65\% of young adults have completed tertiary education, the highest share in the OECD, compared to only $13 \%$ of older adults (Panel B). In addition to these quantitative measures, Korea has consistently ranked near the top in the OECD in the Programme for International Student Assessment (PISA). As Korea has few natural resources, it must rely on the development of its human resources. The extraordinary zeal for education also reflects the fact that economic and social status, and even marriage prospects, are closely linked to educational achievements (Chang, 2009). Graduates are ranked throughout their life based on the prestige of the university that they attended ( $\mathrm{Na}$ and Moon, 2003), thus encouraging serious preparation beginning at a young age. The educational achievements of Korea rest primarily on the intense discipline and work ethic of its students, encouraged and pushed by parents and teachers.

3. Despite its remarkable success in terms of its quantitative expansion and qualitative improvement, there is growing dissatisfaction with the education system. One reason is the high level of stress and anxiety both for parents and students, who spend full days in school, followed by lessons at private tutoring institutes, known as hagwons. In addition, education has imposed high financial burdens on families, creating concerns about the equitable distribution of educational opportunities. In short, the outstanding educational accomplishments in Korea have come at a high cost. Some other OECD countries, in particular Finland, have been able to achieve similarly high results in PISA while avoiding the large-scale use of after-school tutoring and the high level of pressure and stress (Lee, 2010).

1. Randall S. Jones is head of the Japan/Korea Desk in the Economics Department of the OECD. This paper is based on material from the OECD Economic Survey of Korea published in April 2012 under the authority of the Economic and Development Review Committee (EDRC). The author would like to thank Willem Adema, Inyup Choi, Andrew Dean, Robert Ford, Vincent Koen, Minwon Lee, Deborah Roseveare, Miho Taguma, Satoshi Urasawa and Byungseo Yoo for valuable comments on earlier drafts. Special thanks go to Lutécia Daniel for technical assistance and to Nadine Dufour and Pascal Halim for technical preparation.

2. The important role of education in Korean development is widely acknowledged. According to one landmark study of economic growth in East Asia (World Bank, 1993), "Private domestic investment and rapidly growing human capital were the principal engines of growth". 
Figure 1. The rapid expansion of educational attainment in Korea

In 2010

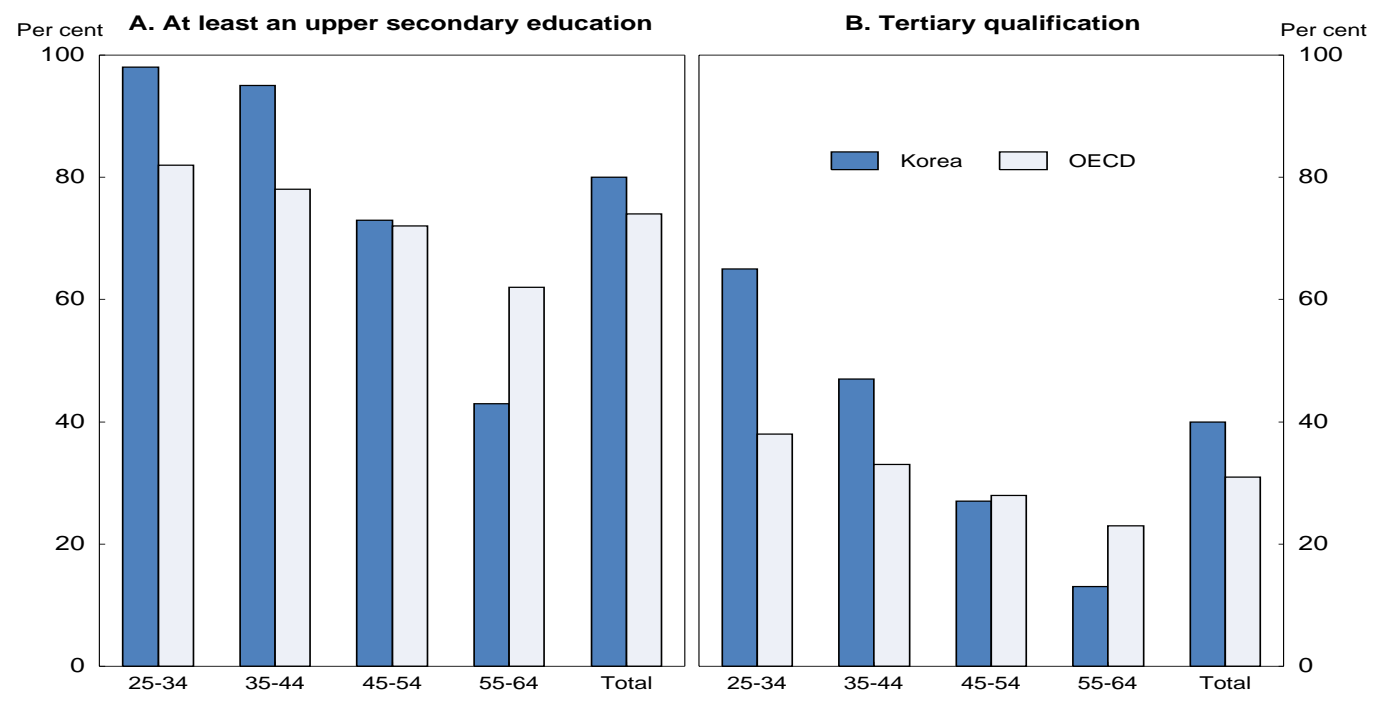

Source: OECD (2012b), OECD Education at a Glance 2012.

4. Further improving the education system requires qualitative reforms to help meet the economic challenges that Korea is facing, while addressing the problems of increasing income inequality and rising relative poverty. After an overview of the education sector, this paper discusses policies to address these challenges. The paper concludes with a summary of recommendations, shown in Box 3.

\section{Overview of the Korean education system}

5. Total spending on education - public and private - as a share of GDP in Korea is the second highest in the OECD area at $8.0 \%$ in 2009 (Figure 2), even before taking account of outlays for private after-school instruction. Moreover, the increase in spending - from 6.1\% of GDP in 2000 - was the largest in the OECD area. Education spending rose from $16 \%$ of government expenditures in 2000 to $20 \%$ in 2008 . Nevertheless, the private sector plays a large role, accounting for $40 \%$ of education spending, the second highest in the OECD area, reflecting its large share at the pre-primary and tertiary levels (Panel B). Expenditure per student relative to GDP per capita in Korea was slightly above the OECD average in 2008 before including outlays for private, after-school instruction.

6. The education system includes nine years of compulsory free education (six years in primary school, followed by three years of middle school). Advancement rates approached $100 \%$ for middle school by 1980 and for high school by 2000 (Figure 3), making Korea one of the few countries in which graduation from high school ${ }^{3}$ is almost universal. In $2011,72.5 \%$ of high school graduates continued on to tertiary education, although this was down from $84 \%$ in 2008 .

\section{Early childhood education and care (ECEC)}

7. ECEC in Korea consists of separate systems of childcare for children under six, based on a social welfare orientation, and education in kindergartens for children aged three to five (Table 1). The two systems remain segmented, with separate facilities and different objectives and curricula (Rhee et al.,

3. This paper will use the terms middle school and high school, which correspond best to the Korean terms 중학교 and 고등학교. 
2008). Kindergarten is administered by the Ministry of Education, while childcare is under the responsibility of the Ministry of Health and Welfare (MHW). There is a bifurcated system of childcare for families at lower socioeconomic levels and working mothers and kindergarten and hagwons for middle and upper-income families (Yun, 2009).

Figure 2. International comparison of total education spending in 2009

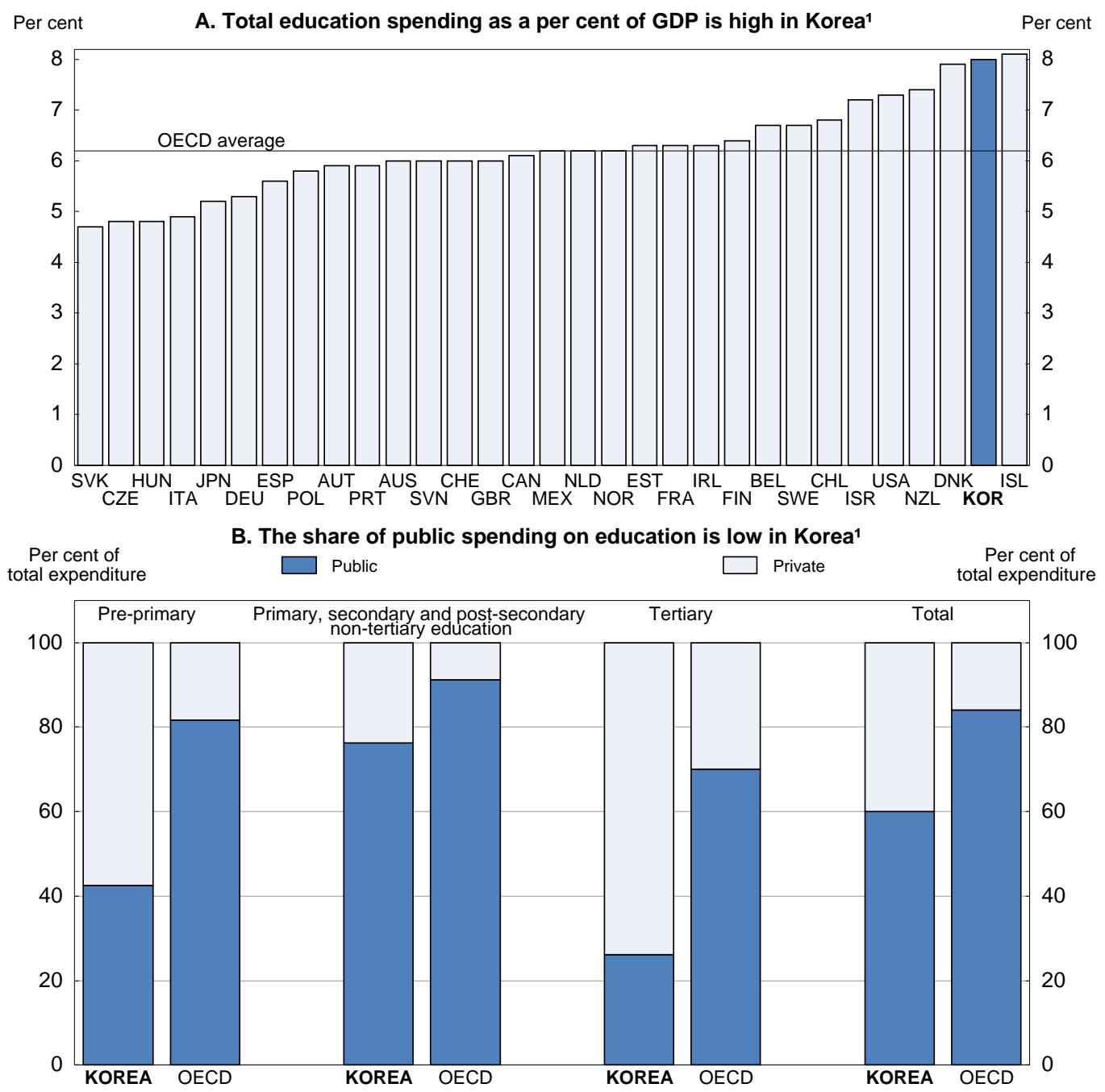

1. For primary, secondary and tertiary education, based on full-time equivalents, in US dollars, converted using PPPs. The figures do not include spending on private institutions, such as hagwons in Korea, which are discussed below.

Source: OECD (2012b), OECD Education at a Glance 2012. 
Figure 3. School advancement rates in Korea

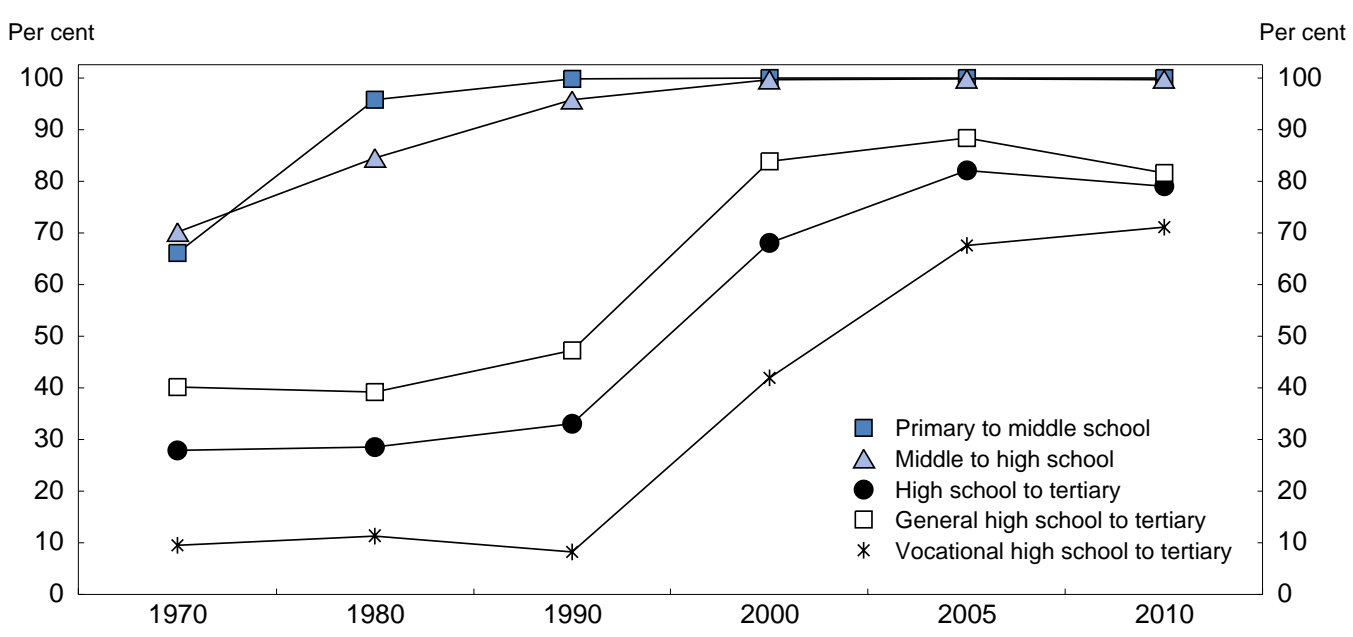

Source: Korean Educational Development Institute (2010).

Table 1. A comparison of childcare centres and kindergarten in 2009

\begin{tabular}{|c|c|c|}
\hline & Childcare centres & Kindergarten \\
\hline Age & 0 to the start of primary school & 3 to the start of primary school \\
\hline Eligibility & Open to all children ${ }^{1}$ & Open to all children ${ }^{2}$ \\
\hline Hours per day & 9 to 12 hours per day & $\begin{array}{l}\text { Half-day: } 3-5 \text { hours } \\
\text { Extended-day: } 5-8 \text { hours } \\
\text { Full-day: more than } 8 \text { hours }\end{array}$ \\
\hline Term period & All year & At least 180 days per year \\
\hline $\begin{array}{l}\text { Governing body } \\
\text { Number of facilities }\end{array}$ & Ministry of Health and Welfare & Ministry of Education ${ }^{3}$ \\
\hline $\begin{array}{l}\text { Public } \\
\text { Private }\end{array}$ & $\begin{array}{r}1917(5.4 \%) \\
33636(94.6 \%)\end{array}$ & $\begin{array}{l}4490(53.6 \%) \\
3880(46.3 \%)\end{array}$ \\
\hline $\begin{array}{l}\text { Number of children } \\
\text { Public facilities } \\
\text { Private facilities }\end{array}$ & $\begin{array}{r}129656(11.0 \%) \\
1045343(89.0 \%)\end{array}$ & $\begin{array}{l}125305(23.3 \%) \\
411825(76.6 \%)\end{array}$ \\
\hline $\begin{array}{l}\text { Government spendin } \\
\text { Share of GDP } \\
\text { Per child in won }\end{array}$ & $\begin{array}{c}0.4 \% \\
3.2 \text { million }\end{array}$ & $\begin{array}{c}0.2 \% \\
2.8 \text { million }\end{array}$ \\
\hline
\end{tabular}

1. Priority is given to children; i) in poverty; ii) in low-income families; and iii) of working mothers and single parents.

2. In case of excess demand, lotteries may be used to allocate spots.

3. Known as the (the Ministry of Education, Science and Technology (MEST) before March 2013.

4. Excluding unlicensed facilities and hagwons.

Source: Ministry of Education, Science and Technology.

8. Rising female employment and the demand for education at an ever-younger age has driven demand for ECEC. The government has supported the expansion of ECEC, primarily by subsidising tuition fees through a voucher system, while the private sector played the major role in establishing and operating ECEC facilities. In 2009, 61.6\% of the under-six age group were enrolled in childcare or kindergarten (Table 2). The share in childcare peaks at $54.4 \%$ for two-year-olds and then falls as an increasing share of children switch to kindergarten. For the three-to-five age group, enrolment is evenly split with about $40 \%$ each attending childcare and kindergarten. In addition, a large number of children attend private 
institutions known as hagwons, instead of or in addition to childcare and kindergarten. Hagwons are primarily focused on academics, teaching children particular skills, particularly in foreign languages and mathematics, as well as music and art. However, there are no data on attendance at hagwons, which are not eligible for the financial support that the government provides to childcare centres and kindergartens (Box 1). Moreover, parents do not receive public subsidies to defray the cost of hagwons.

Table 2. Enrolment in childcare and kindergarten Thousand children in 2009

\begin{tabular}{cccccccc}
\hline Age & $\begin{array}{c}\text { Number of } \\
\text { children } \\
(\mathrm{A})\end{array}$ & $\begin{array}{c}\text { Childcare } \\
(\mathrm{B})\end{array}$ & $\begin{array}{c}\text { Rate } \\
(\mathrm{B} / \mathrm{A})\end{array}$ & $\begin{array}{c}\text { Kindergarten } \\
(\mathrm{C})\end{array}$ & $\begin{array}{c}\text { Rate } \\
(\mathrm{C} / \mathrm{A})\end{array}$ & $\begin{array}{c}\text { Total enrolled } \\
(\mathrm{B}+\mathrm{C}) / \mathrm{A})\end{array}$ & $\begin{array}{c}\text { Employment rate } \\
\text { of mothers }\end{array}$ \\
\hline 0 & 424.5 & 107.5 & 25.3 & 0.0 & 0.0 & 25.3 & 24.7 \\
1 & 464.3 & 198.8 & 42.8 & 0.0 & 0.0 & 42.8 & 29.2 \\
2 & 492.5 & 268.0 & 54.4 & 0.0 & 0.0 & 54.4 & 39.2 \\
$0 \sim 2$ & 1381.3 & 574.4 & 41.6 & 0.0 & 0.0 & 41.6 & 29.9 \\
\hline 3 & 447.4 & 228.0 & 50.9 & 111.5 & 24.9 & 75.9 & 44.4 \\
4 & 434.7 & 193.9 & 44.6 & 181.4 & 41.7 & 86.4 & 44.8 \\
5 & 473.1 & 152.4 & 32.2 & 244.7 & 51.7 & 83.9 & 46.0 \\
$3 \sim 5$ & 1355.2 & 574.3 & 42.4 & 537.6 & 39.7 & 82.0 & 44.9 \\
\hline $0 \sim 5$ & 2736.5 & 1148.7 & 42.0 & 537.6 & 19.6 & 61.6 & 35.8 \\
\hline
\end{tabular}

Source: Suh and Kim, 2010. 


\section{Box 1. Cost and financing of early childhood education and care in Korea}

The cost of ECEC varies by region, but public kindergarten is the least expensive, followed by childcare (public and private), with private kindergarten more expensive. For example, in Seoul in 2010, basic monthly fees for four and five-year-olds ranged from 115 thousand won for public kindergartens (around \$100), to 172 thousand won for public childcare, 238 thousand won for private childcare and between 90 thousand and 540 thousand won for private kindergarten. Basic fees at public and private childcare centres are similar as the government imposes price ceilings on private centres. However, private kindergartens do not face private ceilings.

Government support for ECEC has focused on reducing the fees paid by households through subsidy programmes:

- Income-based subsidy: Since 1991, the government has provided means-tested subsidies, beginning with families below or near the minimum cost of living. By 2009 , eligibility had been expanded to the lower $70 \%$ of the income distribution, with the subsidy covering between $30 \%$ and $100 \%$ of basic fees for public childcare or kindergarten (Suh and Kim, 2010). ${ }^{1}$ In 2011, the subsidy was raised to $100 \%$ of basic fees for all households in the lower $70 \%$.

- Free ECEC for five-year-olds: The government announced in 1997 a goal of providing free ECEC to all children aged five. Implementation, though, was delayed by the eruption of the financial crisis that year, and began only in 1999 for low-income families. Eligibility was gradually expanded to include the lower $70 \%$ of the income distribution by 2010 , and it covers all five-year-olds from 2012 . The amount of the subsidy, though, remains well below the cost of private kindergartens.

- Subsidy for large families: The government provided subsidies for ECEC for families in the lower $70 \%$ income bracket beginning with the second child in an effort to boost the birth rate. This programme was eliminated in 2011 as the subsidy amount was raised to $100 \%$ for all children in families in that income range.

- Subsidy for families in which both parents worked: Given that dual-income couples generally earn more than the $70 \%$ limit, they were allowed to deduct $25 \%$ of their income to qualify for the subsidy beginning in 2010 .

Subsidies are provided by local governments through a voucher system. Parents apply at local governments and if their application is accepted, the subsidy amount is deducted from the fees that they pay to the ECEC facility. Providing subsidies to parents has a number of advantages: $i$ ) it gives them more choice in selecting an ECEC supplier; and ii) it strengthens competition among ECEC providers and raises their cost-consciousness.

\section{Childcare}

Government childcare spending doubled from $0.19 \%$ of GDP in 2006 to $0.37 \%$ in 2010 (Table 3). Subsidies for childcare fees accounted for $92.8 \%$ of the increase, led by the income-based subsidy, even though the amount of subsidies for free childcare for five-year-olds has fallen as more shift to kindergarten or to hagwons. By $2009,71 \%$ of children enrolled in childcare received subsidies, which averaged 340 thousand won (around \$315) per month. ${ }^{2}$ In addition to the subsidies for parents explained above, the government subsidises the operating costs of public facilities (almost entirely for labour costs). ${ }^{3}$ In 2006 , the government introduced a "basic subsidy" for parents with children up to age two in private facilities, which essentially matches the operating subsidy for labour costs that is provided to public facilities. The goal was to reduce the difference in the cost of public and private centres (Rhee, 2007a). In contrast to the rising subsidies to parents, subsidies to childcare centres have stagnated, while investment in childcare facilities and infrastructure has declined.

In addition, the government introduced a child-rearing allowance in 2009 for infants under age two in low-income families that do not use childcare facilities. The allowance, though, is only 100 thousand won per month, well below childcare subsidies, and only $9 \%$ of children under age two qualified for this allowance. Consequently, outlays amounted to only $3 \%$ of childcare spending in 2010 . The eligibility for the allowance was raised to age three in 2011.

\section{Kindergarten}

Government spending on kindergarten, which enrolls about one-half as many children as childcare, is one-third as large at $0.12 \%$ of GDP in 2009 . This spending is divided into: 


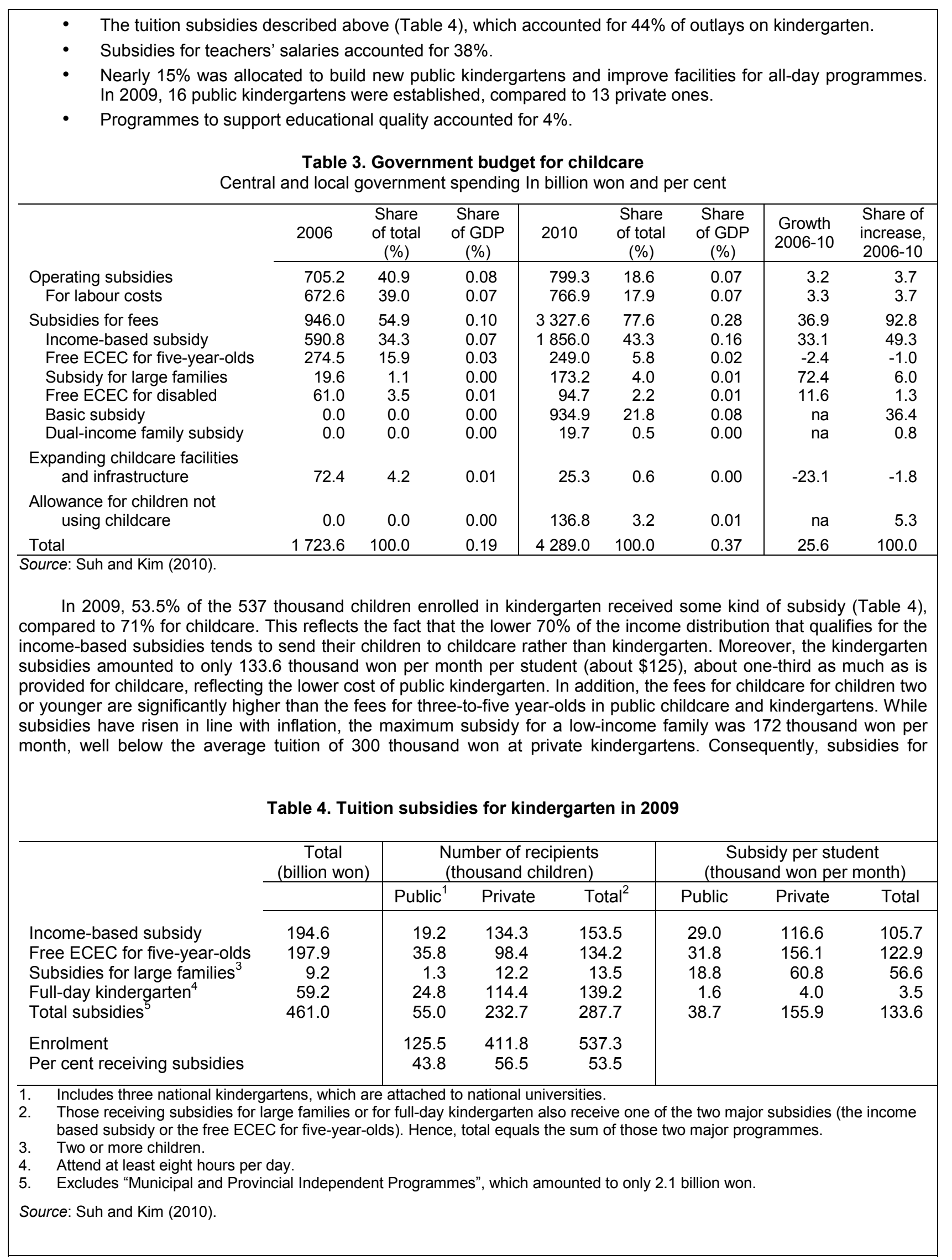


kindergarten amounted to only $0.05 \%$ of GDP compared to $0.28 \%$ for childcare, reflecting the fact that kindergarten is considered to be primarily a private-sector service, notwithstanding its important role in providing care for children. Despite the objective of free ECEC for five-year-olds, the share of three-year-olds receiving subsidies for kindergarten $(56.4 \%)$ was higher than for those aged five $(53.5 \%)$.

Despite growing public financial support, there remain many complaints from households about the burden of paying for ECEC. In a study of parents of children enrolled in ECEC, 51\% cited the heavy burden of costs as the largest dissatisfaction with ECEC services (Yoo et al., 2008). Moreover, according to a study of parents who had withdrawn their children from ECEC or had never enrolled them, the primary reason was the cost (Lee and Lee, 2009). However, the costs are not high relative to other OECD countries. For a family in which both parents earn the average wage, net childcare costs amounted to $15 \%$ of the average wage compared to the OECD average of $18 \%$ (OECD, 2011b).

1. The subsidy was $100 \%$ of fees for those in the lower half of the income distribution. For those in the sixth income decile, the subsidy rate was $60 \%$ and fell to $30 \%$ for the seventh income decile (Suh and Kim, 2010).

2. In addition to the central government, local governments offer additional childcare subsidies. For example, Seoul pays part of the fees to a third child and beyond enrolled in childcare and Busan pays them to the second child and beyond.

3. The government pays $80 \%$ of the salary for workers caring for infants and $30 \%$ for those teaching children.

\section{Childcare}

9. Childcare has developed rapidly during the past two decades, driven in part by rising female employment. The number increased from only 48 thousand children - $1 \%$ of children under age six - in 1990 to 1.15 million in $2009,42 \%$ of the age group (Figure 4). The share of children in public centres fell from $25 \%$ in 1995 to only $11 \%$ in 2009 (Table 5), with a similar decline in centres run by non-profit organisations. Nevertheless, public centres tend to play an important role in low-income areas where private centres are less prominent. It should be noted that childcare centres are just one choice on a menu of options for parents. According to a 2005 government survey, $43 \%$ of working mothers sent their children to childcare centres. Other options used in combination or instead of childcare centres included relatives (45\%), kindergarten and hagwons (41\%) and visits by tutors (28\%) (Kim, 2007).

\section{Figure 4. The expansion of childcare since 1990}

Number of children enrolled by type of institution and share of children under the age of six that are enrolled

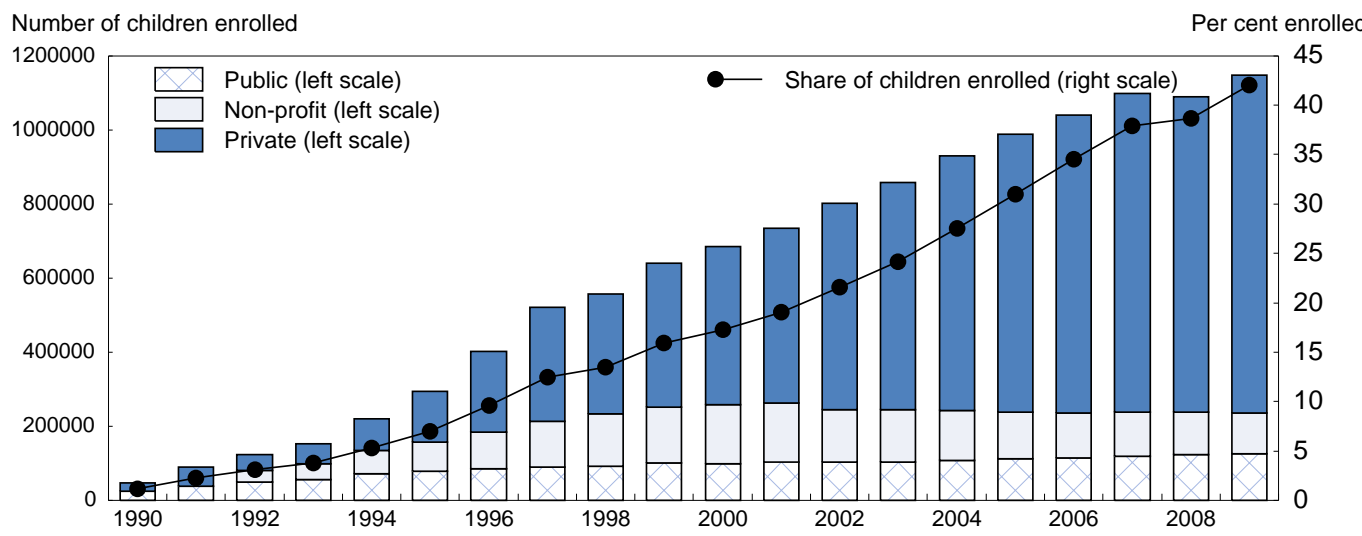

Source: Suh and Kim (2010).

10. Increased subsidies for fees helped reduce the total cost of childcare for households from $8.3 \%$ of their income in 2004 to $7.4 \%$ in 2009 (Table 5). Nevertheless, the burden on families remains substantial, particularly at private institutions founded by individuals, which account for more than half of children enrolled in childcare. While government subsidies reduced basic childcare fees from 136.4 thousand won per month in 2004 to an average of 114.3 thousand won in 2009, this was offset by an increase in additional fees, such as entrance fees and payments for fieldtrips and educational costs. Additional fees are 
particularly high at private institutions founded by individuals, boosting their total cost to $8.1 \%$ of household income, compared to $6.1 \%$ in public institutions. This trend illustrates the challenge of reducing the fees paid by parents: higher government subsidies to reduce basic fees are offset by increases in additional fees.

Table 5. Childcare fees paid by households

Thousand Korean won and per cent in 2009

\begin{tabular}{|c|c|c|c|c|c|c|}
\hline Type of establishment & $\begin{array}{c}\text { Share of } \\
\text { children (\%) }\end{array}$ & $\begin{array}{l}\text { Number of } \\
\text { children } \\
\text { per centre }\end{array}$ & Basic fee & $\begin{array}{l}\text { Additional } \\
\text { fees }\end{array}$ & Total cost & $\begin{array}{l}\text { Share of } \\
\text { household } \\
\text { income (\%) }\end{array}$ \\
\hline Public & 11.0 & 67.6 & 86.7 & 39.8 & 126.6 & 6.1 \\
\hline Non-profit corporations & 9.6 & 76.4 & 69.5 & 41.5 & 110.9 & 5.4 \\
\hline For-profit corporations & 4.5 & 56.4 & 103.2 & 40.5 & 143.7 & 6.6 \\
\hline Private (individuals) & 53.0 & 46.4 & 124.5 & 63.9 & 188.4 & 8.1 \\
\hline Home-based care & 20.2 & 13.6 & 133.1 & 29.9 & 163.0 & 7.3 \\
\hline Workplace & 1.6 & 50.8 & 164.3 & 64.9 & 229.2 & 5.4 \\
\hline Parent co-operatives & 0.1 & 25.1 & 96.9 & 2.6 & 99.5 & 6.1 \\
\hline Total & 100.0 & 33.1 & 114.3 & 53.8 & 168.1 & 7.4 \\
\hline \multicolumn{7}{|l|}{ Memorandum item: } \\
\hline 2004, all establishments & & & 136.4 & 28.3 & 164.7 & 8.3 \\
\hline
\end{tabular}

11. Childcare fees remain significant, even for families receiving subsidies. About a third of children enrolled in childcare were categorised as "exempted" from basic fees and another one-third as entitled to "reduced" fees in 2009 (Table 6). For children classified as exempted, the cost of childcare still amounts to some $4.6 \%$ of their household income, although well below the $9.6 \%$ of household income for families not receiving subsidies. Still, childcare costs less than kindergarten (see below) and consequently, low-income families tend to use childcare facilities, where they bear less of the financial burden.

Table 6. Childcare fee by exemption status

Thousand Korean won and per cent in 2009

\begin{tabular}{lccccc}
\hline Fee status & $\begin{array}{c}\text { Share of } \\
\text { children }\end{array}$ & Basic fee & $\begin{array}{c}\text { Additional } \\
\text { fees }\end{array}$ & Total cost & $\begin{array}{c}\text { Share of } \\
\text { household income }\end{array}$ \\
\hline Exempted & 35.0 & 10.7 & 44.3 & 55.0 & 4.6 \\
Reduced & 36.0 & 108.5 & 56.7 & 165.2 & 7.8 \\
General & 29.0 & 246.8 & 61.8 & 308.6 & 9.6 \\
Total & 100.0 & 114.3 & 53.8 & 168.1 & 7.4 \\
\hline
\end{tabular}

1. Parents still pay some basic fees as the cost at some private childcare institutions exceeds the amount of the subsidy.

Source: Suh and Kim (2010).

12. By 2009, nearly four-fifths of children in childcare were enrolled in private, for-profit centres (Table 5). Such institutions tend to be relatively small, particularly for home-based care, with an average of less than 40 children per centre, compared to 67.6 in public centres and 76.4 in non-profit centres. A number of indicators suggest that quality in private, for-profit centres is relatively low. First, under the accreditation system introduced in 2006, $97 \%$ of public centres had been accredited by the end of 2011, but 
only $74 \%$ of private centres. Second, teacher qualifications are higher in public and non-profit institutions. ${ }^{4}$ Working in private childcare centres is a low-wage profession that requires only one year of training following high school.

13. In addition to better teachers and facilities, public centres are less expensive by 50 thousand to 60 thousand won (\$45 to \$55) per month (Women's Daily, 22 April 2011), despite ceilings imposed on fees charged by private centres. Private centres' fees vary by region based on the ceilings set by the 16 provincial and metropolitan city governments. The ceilings are intended to improve access to childcare. However, the fees are set below the minimum level needed to provide quality childcare, according to the government. ${ }^{5}$ Beginning in 2011, private centres that meet certain standards have been allowed on a trial basis to charge fees $50 \%$ above the ceiling. In another effort to boost the supply of private childcare, the Ministry of Health and Welfare will ease 51 regulations on the establishment of such facilities. ${ }^{6}$

14. There are waiting lists to enter public childcare centres, given their lower cost and generally higher quality. In 2009, the waiting list for the 1917 public centres reached 118 thousand children, nearly matching the number of children enrolled (130 thousand) (Suh and Kim, 2010). According to a survey by the National Assembly, only one out of ten children under age six in Seoul attends public childcare facilities, and one out of eight children is on the waiting list to enter such a facility (Simin Daily, 17 November 2010). Consequently, there are widespread complaints about a lack of affordable, high-quality childcare. At the same time, private centres have significant excess supply. In 2009 , more than $20 \%$ of their places were unfilled, leaving excess capacity of 0.3 million.

15. Workplaces with over 300 full-time female workers or over 500 workers in total are legally required to operate a childcare centre for their employees' children. According to a survey of parents, workplace-based childcare was cited by $46 \%$ as the most suitable (Yonhap News, 27 March 2011). By mid2008 , there were 335 childcare facilities in workplaces, indicating that $43 \%$ of workplaces required to provide such facilities did not meet their obligations, reflecting the lack of penalties for violators (Asia Economic, 23 October 2010). However, firms are demanding more financial assistance to help finance workplace-based childcare facilities.

\section{Kindergarten}

16. As noted above, nearly $40 \%$ of children between the age of three and five are enrolled in kindergarten, both public and private (Table 2). As in the case of childcare, the private sector played the leading role in the development of kindergartens, accounting for nearly three-quarters of the increase in students since 1980 (Figure 5). In 2009, 76.6\% of the students in kindergarten attended private institutions. While there are more public than private kindergartens, private institutions tend to be larger (4.6 classes per school compared to 1.5 for public kindergartens) and are located primarily in urban areas where parents are able to pay for services. For example, $92 \%$ of kindergarten students in Busan are in private institutions.

4. The share of teachers classified as Grade 1 was $80 \%$ for public institutions and $74 \%$ for non-profit ones in 2009 , compared to $53 \%$ in private, for-profit centres. The quality difference is reflected in the wage gap between public and private centres.

5. For example, for children less than one-year-old, the cap was set at 361000 won per month in 2007, with the government providing a subsidy of 292000 won. The combined amount (663 000 won) was well below the 789000 won that the government calculates is necessary to provide adequate care (2008 OECD Economic Survey of Korea).

6. For example, childcare facilities, which had been limited to the first three floors of a building for safety reasons, can now be established on the 4 th and 5 th floors. 
Figure 5. The growth of kindergarten since 1980

Number of children enrolled and share of children between the ages of three and five

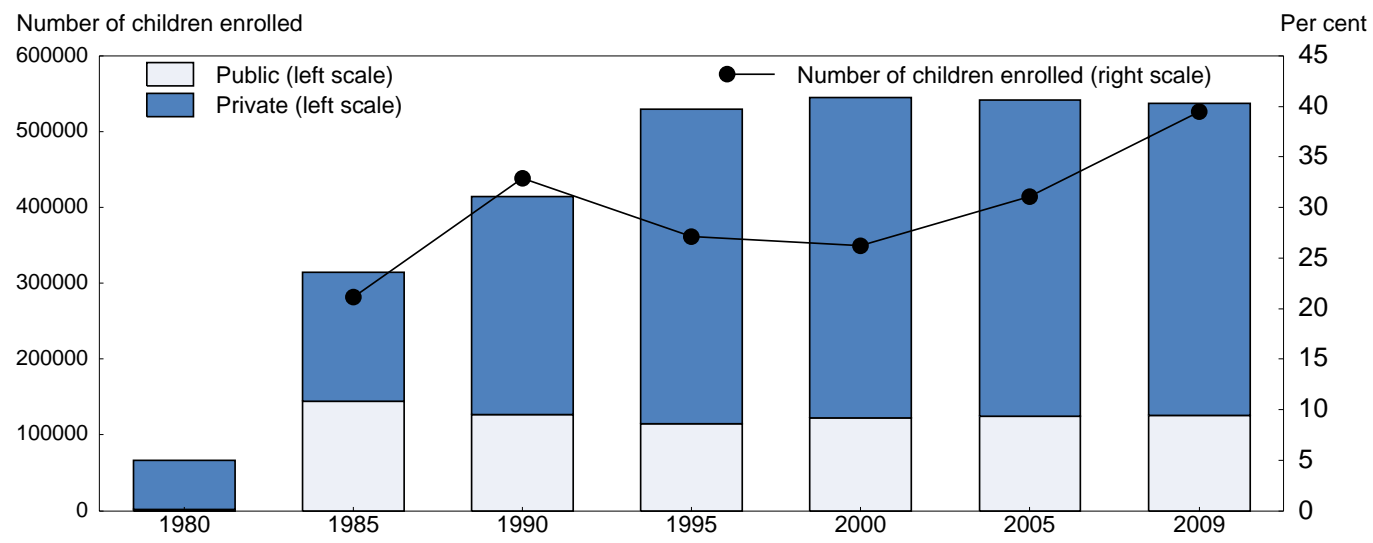

Source: Suh and Kim (2010).

17. Public kindergartens are located primarily in rural areas. For example, in rural Cheongbuk province, one-third of kindergarten students are in public institutions. Although public kindergartens enroll less than a quarter of students nationwide, they receive $59 \%$ of public-sector spending on kindergartens. Consequently, public spending per student in public kindergartens is 4.6 times higher than at private ones. Public kindergartens are thought to be superior in quality mainly due to the teachers, who have to meet the requirements to be a public official. Consequently, 66\% hold degrees from four-year universities, compared to only $30 \%$ for the sector as a whole, indicating a much lower share for private kindergartens (Na and Moon, 2003). In addition, public kindergarten teachers have longer tenure; $76 \%$ have taught more than ten years, while in private kindergartens, $80 \%$ have less than five years of experience.

18. Enrolment in kindergarten has fallen by $1.5 \%$ since its peak in 2000, as a decline in students in private institutions more than offset a small increase in public ones (Figure 5). The overall decline reflects the falling number of pre-primary age children and the rising enrollment in childcare (Figure 4). The increase in childcare - at the expense of private kindergartens - reflects the fact that it is less costly (Box 1), prompting many families, particularly those with lower incomes, to opt for childcare. Kindergarten, in contrast, is mainly dependent on private resources. In addition to its higher cost, kindergarten has traditionally offered a three to five-hour daily programme, which is less convenient as the rising number of dual-income families has increased the need for full-time childcare. In response, the government has been encouraging the introduction of full-day kindergartens since the 1990s. By 2008, 91\% of kindergartens, accounting for $54 \%$ of students, were offering full-day programmes. However, the full-day programmes face a number of problems, including inadequate educational content and insufficient facilities and staff (Moon, 2010). Moreover, the fact that kindergartens offer services for only 180 days a year is another stumbling block for dual-income families. Another factor reducing the role of kindergartens is the growing role of hagwons for pre-primary age children.

19. There has been some convergence in childcare and kindergarten in recent years, according to some experts ( $\mathrm{Na}$ and Moon, 2003). Nevertheless, in a survey of parents, $78 \%$ replied that there are significant differences between kindergarten and childcare, with the most significant found in educational content and programmes (Yoo et al., 2008). The government has developed the "Nuri Curriculum", which aims to harmonise the kindergarten and childcare programmes for five-year-olds. It has been taught three to five hours a day since its introduction in 2012. The new curriculum was extended to three and four-yearolds in 2013. 


\section{Primary and secondary education}

20. In the 2009 PISA assessment, Korea ranked first among OECD countries in mathematics and reading and third in science (Figure 6). Moreover, Korea's overall performance in PISA has improved since 2006, when it was $11^{\text {th }}$ in science, fourth in math and first in reading. Since 2000, Korea has doubled the share of students demonstrating excellence in reading literacy: $13 \%$ of its students were proficient at level five or above compared to an OECD average of $8 \%$. While Korea ranks very highly among OECD countries, it faces increasing competition from emerging economies. In the 2009 PISA results, Shanghai ranked above Korea in all three subjects, while Hong Kong, China and Singapore were above Korea in mathematics and science.

Figure 6. International comparison of student performance on the PISA test

Student performance at age 15 in 2009

A. Mathematics

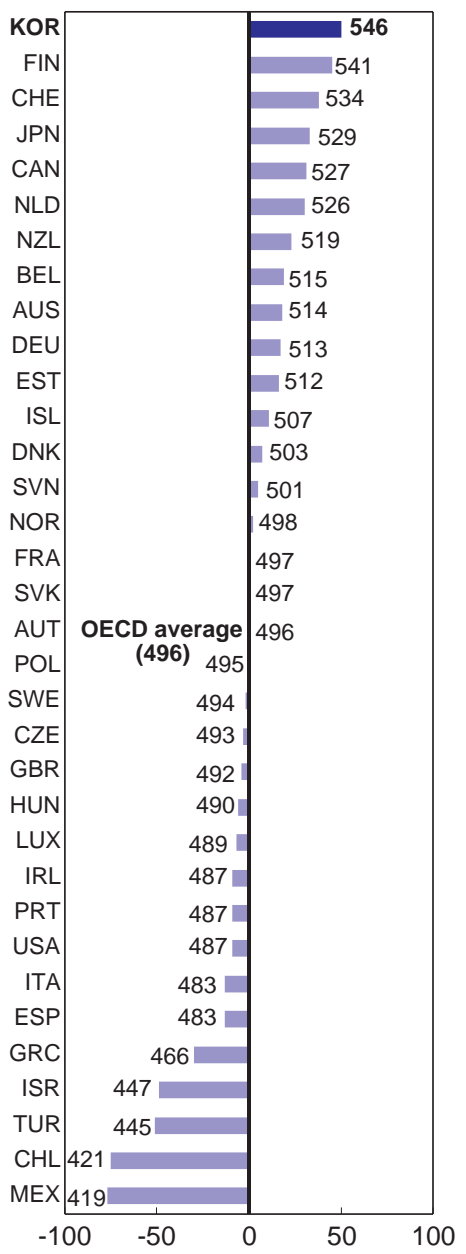

B. Reading

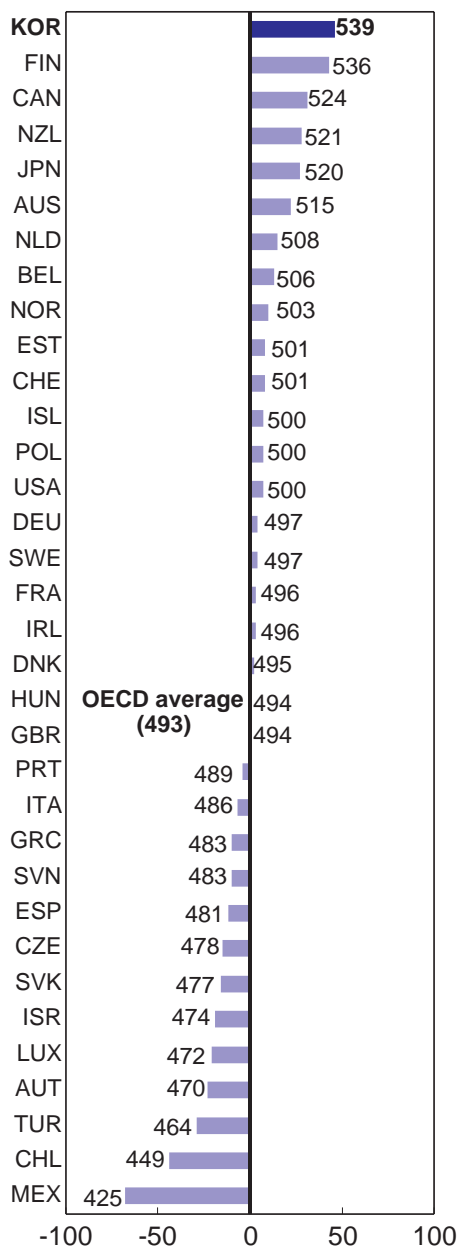

C. Science

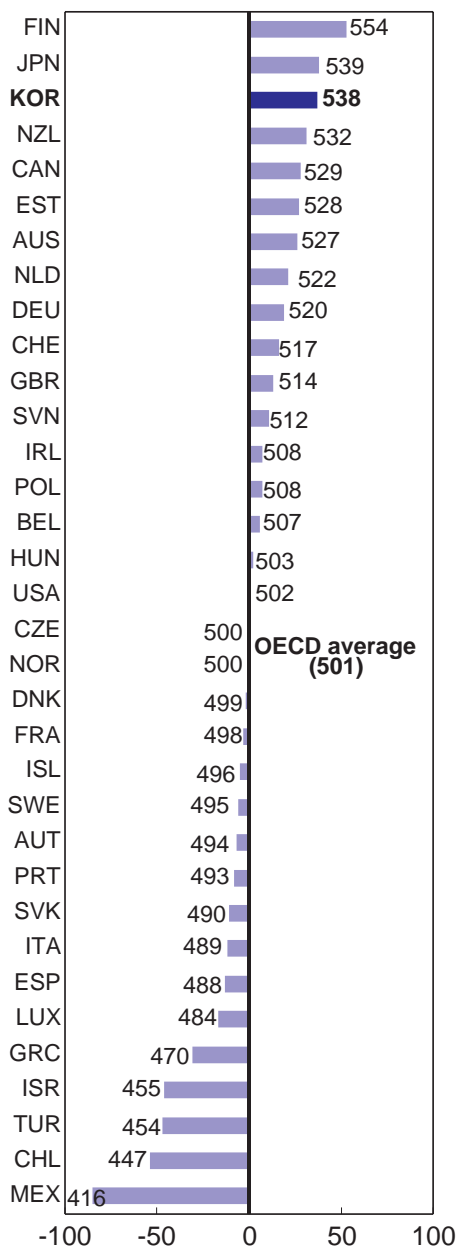

Source: OECD (2010d), PISA 2009 Results: What Students Know and Can Do, Volume I.

21. Responsibility for primary and secondary education in the 16 provinces and metropolitan cities is vested in education boards and offices of education, which are separate from local general governments. The offices of education play an executive role in allocating spending, managing facilities and hiring and training staff, while the education boards have authority to make decisions related to education. Compared to local general governments, the local education authorities are more dependent on transfers from the central government, which accounted for three-quarters of their budget in 2010. The transfers are almost 
entirely from the Local Education Share Tax, which is a fixed proportion of national tax revenue (excluding earmarked taxes and duties). The share was increased from $20.0 \%$ to $20.27 \%$ in 2010 . Another $18 \%$ is financed by earmarked taxes by local general governments, ${ }^{7}$ which are legally responsible for some expenses, such as purchasing land for school buildings. In contrast, the share of local education governments' own resources, such as tuition fees and local bonds, is less than $10 \%$. The share of privatesector spending on primary and secondary education is the highest in the OECD area at $22 \%$, in part due to tuition fees that are still required for high school.

22. The activities of the local education authorities are subject to review and approval by local general governments, but have a significant degree of independence in formulating and spending their budgets. However, the discrepancy between their spending responsibilities and limited funding capacity restrains their autonomy. Moreover, the central government's major financing role has discouraged financing from the local general governments (Jones and Yokoyama, 2005). One of the objectives of the 2006 "Roadmap for Decentralisation" was to enhance local autonomy in education through stronger linkages between local general government and educational authorities and participation by residents. Local Educational Administrative Councils were created as a tool for such co-operation and direct election of superintendents of local education offices was introduced, thus increasing their accountability to local residents.

23. In addition to co-ordination with local general governments, local education authorities' policies must conform to central government regulations. If not, the central government gives correction orders or other direction. Indeed, the law states that the Minister of Education may "advise and guide" the affairs of local education boards. The shift toward greater autonomy for local education governments in recent years has been accompanied by greater conflict with the central authorities due to different policy directions and interpretation of legislation.

24. Teachers' salaries are high in Korea, helping to attract considerable talent to the teaching profession. Indeed, the top of the pay scale for primary school teachers, \$74 thousand (at PPP exchange rates), was $64 \%$ higher than the OECD average in 2012 even though per capita income in Korea was about one quarter below the OECD average (OECD, 2012b). The ratio of teachers' salaries at the top of the pay scale relative to the starting salary in Korea was the highest in the OECD area, reflecting the steepest tenure/salary curve among member countries, thus encouraging teachers to remain in the profession. Moreover, teaching time at the secondary level in Korea was 9\% below the OECD average in 2010.

25. School curricula are heavily shaped by the College Scholastic Aptitude Test (CSAT), a multiplechoice exam that is a key determinant of admission to university. ${ }^{8}$ Exams in high school, generally twice a semester, also play an important role. According to one study, students had to memorise 60 to 100 pages of facts for each exam to do well. The focus on a multiple-choice test gives an important role to learning facts, which is consistent with the Asian tradition of teaching dominated by the transfer of information from teacher to student. However, such an approach is less effective in fostering independent thought and creative and flexible thinking (OECD, 2009). The authorities have acknowledged the need to emphasise creativity and character education. In 2009, a revised curriculum including "Creative Experiential Learning Activities" was introduced, while reducing academic content by $20 \%$. Since 2008 , the results of schools' performance in the National Assessment of Educational Achievement and school evaluation reports have been publicly available (http://www.schoolinfo.go.kr), thereby enhancing transparency about performance.

7. The share of local tax revenue transferred to the educational authorities is $10 \%$ in Seoul, $5 \%$ in other metropolitan cities and Gyeonggi Province and 3.6\% for other provinces.

8. The CSAT, which can be taken only once a year, has five subjects: Korean language/reading, English, math, foreign languages and elective subjects in social and physical sciences. 
26. Under the "equalisation policy", students are assigned randomly to middle and high schools (both public and private $)^{9}$ in their district through a lottery system, replacing the earlier system of entrance exams. While this reduces pressure on students and promotes equality, it reduces diversity and competition between schools, undermining incentives for schools to respond to the needs of students and their parents (Kim and Lee, 2003). Moreover, the policy limits the autonomy of schools (Chang, 2009). Korea has two types of high schools: general, aimed at preparing students for tertiary education, and vocational, originally aimed at preparing them for employment. ${ }^{10}$ However, vocational high schools have become less popular, with their share of students falling from $42 \%$ in 1995 to $24 \%$ in 2010 . Moreover, the distinction has become blurred as the share of vocational school graduates advancing to tertiary education climbed from only $8 \%$ in 1990 to $71 \%$ in 2010 , approaching the $82 \%$ figure for general high schools. Thus, vocational institutions have shifted from "terminal institutions" preparing students for employment to sending students to tertiary education. However, $46 \%$ of vocational high school graduates enter colleges, which are more vocationally-oriented, while $25 \%$ study at universities.

\section{The shadow education system: the role of hagwons and other private tutoring institutions}

27. After-school education has been a major factor behind the excellent performance of Korean students in international tests, such as PISA (Koh et al., 2010). In 2010, around three-quarters of students participated in such courses (Table 7). According to the PISA, the participation of 15-year-old students is more than double the OECD average in every subject (Figure 7). Indeed, Korea ranks first in the share of students studying mathematics and science and second (after Japan) in national language in after-school education. Academic subjects account for four-fifths of private tutoring with the remainder divided between music, art and sports. Among academic subjects, English (41\%), mathematics (35\%) and Korean (11\%) were the most important. More than $70 \%$ of students participating in private tutoring attend hagwons, making it the most important player in this sector. It is not uncommon for students to be enrolled in several hagwons focusing on different subject areas. Korea currently has nearly 100 thousand hagwons, which must receive a permit from the local education government to operate. The concentration of around 6000 hagwons in the Kangnam district of Seoul is thought to be an important factor in the high housing prices in that area, which has become a major social issue. The hagwons have more teachers than the public school system and attract the best ones with higher salaries. Admission to prestigious hagwons is challenging and depends on entrance exams. ${ }^{11}$ In addition to hagwons, private after-school education includes individual or group tutoring and Internet and distance learning.

28. Total spending on private tutoring in 2010 fell $3.5 \%$ in nominal terms from 2009, reflecting a decline in participation from $75.0 \%$ of students to $73.6 \%$. Outlays per student participating in private tutoring, though, rose by $1.2 \%$. Total spending increased from $1.2 \%$ of GDP in 1999 (Ministry of Education, 2000) to $1.8 \%$ in 2010 , representing $7.9 \%$ of average household disposable income (Table 7 ).

9. According to one study, the equalisation policy led to the "virtual nationalisation" of private schools, as they lost control over the selection of students and had no incentives to adopt policies to attract students (Kim and Lee, 2003).

10. Vocational high schools, renamed professional high schools in 2008, offer programmes in five fields: agriculture, technology/engineering, commerce/business, maritime/fishery and home economics.

11. Only $14 \%$ of applicants for the Daesung Institute are accepted. After one year of study, $70 \%$ gain entrance to one of Korea's top three universities (Time Magazine, 3 October 2011). 
Table 7. Private, after-school education in Korea in 2010

\begin{tabular}{lc|cc|cc|cc}
\hline & $\begin{array}{c}\text { Participation } \\
\text { rate } \\
(\%)\end{array}$ & $\begin{array}{c}\text { Expenditure } \\
\text { per } \\
\text { student }\end{array}$ & $\begin{array}{c}\text { Share } \\
\text { of } \\
\text { income }^{2}\end{array}$ & $\begin{array}{c}\text { Expenditure } \\
\text { per } \\
\text { student }^{3}\end{array}$ & $\begin{array}{c}\text { Share } \\
\text { of } \\
\text { income }\end{array}$ & $\begin{array}{c}\text { Total } \\
\text { expenditure } \\
\text { (trillion } \\
\text { won) }\end{array}$ & $\begin{array}{c}\text { Share } \\
\text { of } \\
\text { GDP } \\
(\%)\end{array}$ \\
\cline { 2 - 7 } Total & 73.6 & 240 & 7.9 & 325 & 10.7 & $\mathbf{2 0 . 8}$ & 1.8 \\
Primary school & 86.8 & 245 & 8.1 & 282 & 9.3 & 9.7 & 0.8 \\
Middle school & 72.2 & 255 & 8.4 & 352 & 11.6 & 6.0 & 0.5 \\
High school & 52.8 & 218 & 7.2 & 408 & 13.4 & 5.1 & 0.4 \\
\hline
\end{tabular}

1. For all students in thousand won per month, regardless of whether they participated in private, after-school education.

2. As a per cent of average household disposable income, based on 2.84 persons per household. To the extent that household income is higher in households with children, the share of income is over-estimated.

3. Per student that participates in private, after-school education in thousand won (total expenditure/(number of students * participation rate in private after-school education).

Source: Ministry of Education, Science, and Technology (2011), Bank of Korea and OECD calculations.

29. Private tutoring has been described as the "enemy of the public school system" (Chung, 2002), prompting government efforts to reduce private tutoring spending (Box 2). In a 2010 government survey that asked parents the reasons for the high level of spending on private tutoring, the answers focused on the difficulty and importance of gaining entry to prestigious universities, which select students primarily based on entrance exam scores (Table 8). Academic credentialism - the emphasis on where a person studied rather than on their abilities, accomplishments or potential - is strong in Korea, based on a well-known ranking of universities (Chang, 2009).

Figure 7. The percentage of students attending after-school lessons in Korea is exceptionally high

By hours per week in 2009

Less than 4 hours per week $\square$ Four hours or more per week
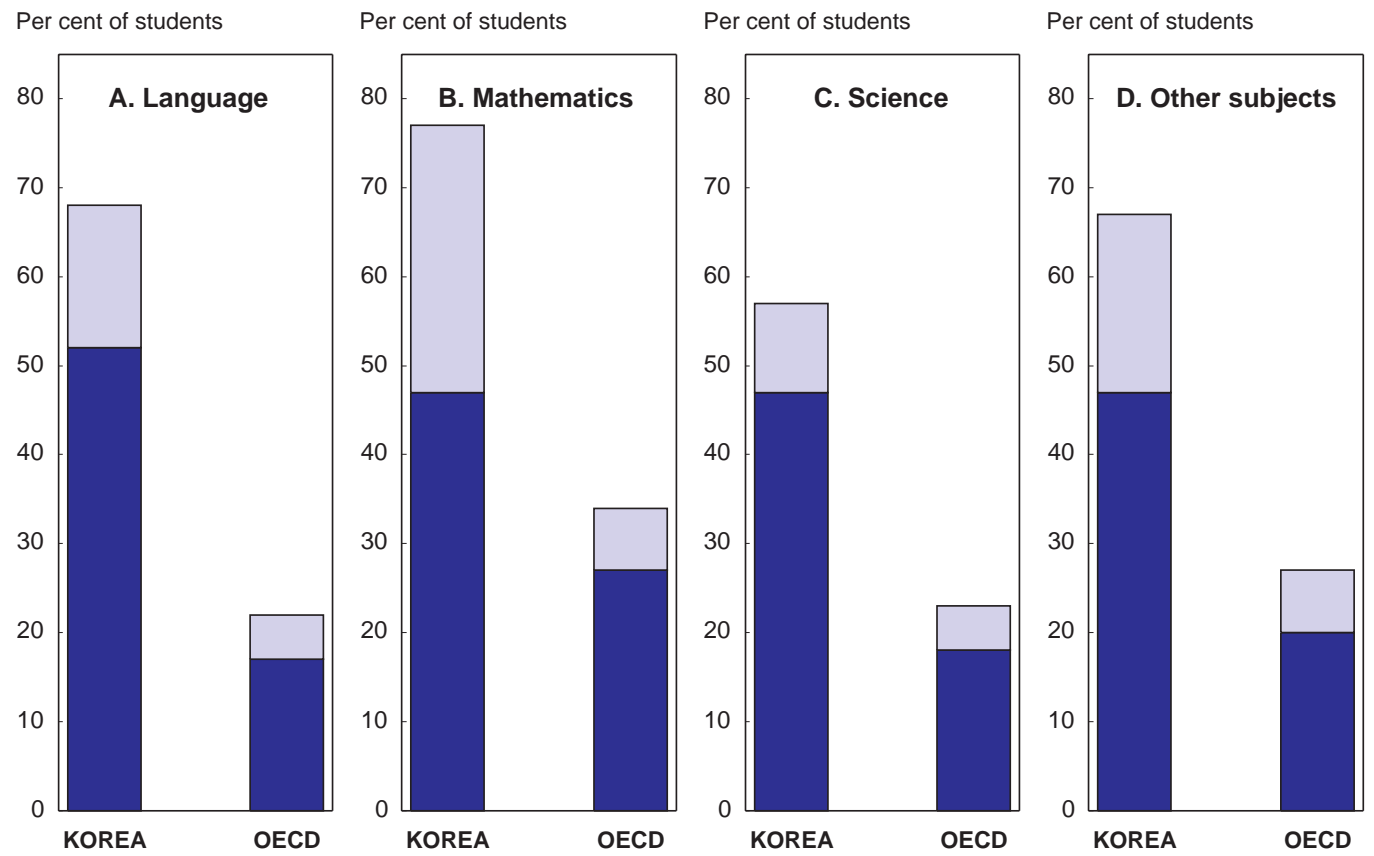

Source: OECD (2010d), PISA 2009 Results: What Students Know and Can Do, Volume I. 
30. The 2010 government survey suggested other reasons for increased private tutoring (Table 8):

- Parents, who are increasingly well educated and have fewer children than past generations, have higher expectations for their children, thus encouraging investment in private tutoring.

- The weakness of public schools is cited in five of the top responses. In particular, public schools are criticised for failing to fully develop students' potential, providing insufficient academic support and individualised teaching and having an unsatisfactory atmosphere. The deterioration of the classroom environment has become a widely discussed phenomenon called "school collapse" (Kim, 2003). Private tutoring thus compensates for weaknesses in public education and provides services tailored to students' individual needs.

- The sixth-most highly ranked reason - that not attending hagwons would place their children at a competitive disadvantage - suggests that private tutoring would play a role regardless of the quality of public schools.

Table 8. Reasons for increasing private tutoring

Five-point scale ${ }^{1}$

\begin{tabular}{|c|c|c|}
\hline Rank & Reasons & Score \\
\hline 1 & The name of the university one graduates from is important for future job prospects & 4.2 \\
\hline 1 & Special purpose high schools and universities select students based primarily on their test scores & 4.2 \\
\hline 3 & Universities have a severe ranking system for admission & 4.1 \\
\hline 4 & $\begin{array}{l}\text { Parents have higher expectations for their children as they have higher levels of education and } \\
\text { fewer children }\end{array}$ & 4.0 \\
\hline 5 & School tests are more difficult than what students learn in regular classes & 3.9 \\
\hline 6 & School education alone cannot develop students' potential and aptitude & 3.7 \\
\hline 6 & Not participating in hagwons worries parents and students, given that hagwons are so prevalent & 3.7 \\
\hline 6 & Economic growth and higher incomes facilitate increased spending & 3.7 \\
\hline 9 & Schools fail to provide tailored learning support to individual students & 3.4 \\
\hline 10 & Schools fail to provide lectures that are differentiated according to students' academic level & 3.3 \\
\hline 10 & Schools provide insufficient support for academic progress, counselling and information & 3.3 \\
\hline 12 & Classroom atmosphere and school equipment are not satisfactory & 2.7 \\
\hline
\end{tabular}

1. The government survey asked parents to rank factors responsible for the increase in private tutoring.

Source: Ministry of Education, Science, and Technology (2011).

\section{The tertiary sector}

31. Tertiary education has expanded rapidly during the past two decades. In 1990, Korea had 1.6 million students attending 148 universities and 117 colleges (generally two-year institution). By 2010, the number of students had doubled to 3.3 million in 371 colleges and universities (Table 9), despite a 17\% fall in the number of high school graduates. Consequently, the tertiary advancement rate (the share of high school graduates advancing to tertiary education) climbed from 33\% in 1990 to a peak of $84 \%$ in 2008 (Figure 3). With such "education inflation", jobs once filled by high school graduates are now filled by those with tertiary degrees. The expansion of the tertiary sector was led by the private sector, which accounted for $80 \%$ of the rise in enrolment. ${ }^{12}$ Private universities accounted for $54 \%$ of the increase in students since 1990, and private colleges for another $26 \%$. In terms of institutions, the number of public

12. According to the QS ranking of universities, ten of the top 15 universities in Korea are private. The QS World University Ranking is based on six indicators: academic reputation based on a global survey (40\%), citations per faculty $(20 \%)$, faculty-student ratio $(20 \%)$, employer reputation (10\%), proportion of international students $(5 \%)$ and proportion of international faculty $(5 \%)$ 
colleges declined slightly over the past 20 years (Table 9, Panel B). In contrast, 71 new private universities were created, encouraged by a liberalisation of the regulations governing the establishment of new institutions, tax breaks for school operations and special government loans.

\section{Box 2. Government policies to limit the role of hagwons and other forms of private tutoring}

Reliance on private tutoring has expanded since the 1960s in response to competitive pressures for educational success and economic growth that expanded the ability of parents to pay for such services. In addition, the government attributed the reliance on after-school tutoring to weaknesses in school education, lack of sufficient public investment in education and parental lack of confidence in schools. Low-income parents tend to resent the advantages of extracurricular help that affluent parents are able to provide to their children, while all parents resent the financial burden of such help. Extra tutoring initially took three main forms: i) classes in hagwons; ii) paying one's regular school teacher for after-hours classes; and iii) hiring a private tutor, typically a university student.

One of the first steps taken against private tutoring was the equalisation policy, which attempted to end "entrance exam hell" by abolishing competitive exams for middle school in 1969 and for high school in 1974. Instead, students in urban areas were allocated to schools in their district by a lottery system, thus eliminating one of the major motivations for hagwons. Moreover, the focus on entrance exams had distorted the curriculum to help students prepare for the exams and led to a significant number of students repeating grades in order to improve their performance. However, the equalisation policy does not end the emphasis on exam preparation but delayed it, as students focused on the CSAT, which determines admission to university.

In 1980, the government took strict measures against private tutoring on the grounds that it unfairly burdened the poor and promoted inequality. It launched the "Measures to Normalise Education and Eliminate Extra-Curricular Study", which banned hagwons and other private tutoring: $i$ ) hagwons were forced to refund fees to their students, effectively closing them; ii) primary and secondary school teachers were forbidden from doing extracurricular tutoring; and iii) university students were prohibited from tutoring non-relatives, although this was very hard to enforce. Students receiving tutoring could be suspended from school. ${ }^{1}$ While the reforms were generally welcomed by students and parents, the continued pressure to succeed academically simply drove the private tutoring industry underground and prompted schools to offer supplementary classes. The ban was finally ruled unconstitutional by the Supreme Court in 2000 on the grounds that it "infringes on the basic rights of the people to educate their children". The government launched a five-year plan to improve the quality of schools by boosting the number of teachers and their salaries, purchasing computers and expanding English classes to compete with private tutoring.

Despite the Supreme Court ruling, there have been subsequent attempts to limit private tutoring. In 2008, for example, the government prohibited school teachers from creating questions for hagwons, to avoid giving those students an unfair advantage. There was an also an effort to prevent private tutoring that is deemed to be "too expensive". The Seoul government required hagwons to disclose their tuition fees and provide receipts to parents and warned that they would lose their license if they are caught running false advertising. It was reported in 2009 that twothirds of hagwons overcharged for tuition, with $40 \%$ demanding twice the agreed amount (Korea Times, 14 April 2009). Finally, Seoul imposed 10 p.m. curfews for hagwons. However, hagwons have been able to mitigate the impact by putting more lessons online for students to buy after the curfew and increasing weekend classes (Time Magazine, 3 October 2011). Other cities have not chosen to impose curfews. Finally, the government announced that $70 \%$ of the questions on the university entrance exam would come from courses shown on the Educational Broadcast System, thus encouraging students to shift their attention away from hagwons.

1. The president of Seoul National University, the top-ranked university in Korea, was forced to resign in 1998 after it was revealed that his child had received private tutoring.

32. Since 2000 , there has been a shift away from colleges, which are primarily two-year institutions. Indeed, their enrolment has fallen by $14 \%$, while the number of university students has risen by $28 \%$. Consequently, universities accounted for more than three-quarters of students by 2010 . The shift away from colleges reflects their lower status; students who have a chance to enter a university will usually not apply to a college, reflecting the rising educational aspirations of young people, especially women. According to a government survey, $93 \%$ of parents expect their children to at least graduate from a fouryear university. Moreover, some companies will not hire college graduates. With universities entering the traditional domain of colleges, it is becoming more difficult for college graduates to find jobs in the face of 
competition from university graduates. Indeed, the wage premium for college graduates relative to those with only high school degrees has virtually disappeared. The shift away from colleges has several negative implications. First, it may weaken vocational education, the traditional focus of colleges. Second, it is creating financial distress in colleges, as the number of students per institution declines, reflecting their dependence on tuition payments (see below).

Table 9. Expansion of the tertiary sector

\begin{tabular}{|c|c|c|c|c|c|c|c|c|c|}
\hline \multicolumn{10}{|c|}{ A. Change in the number of students (thousands of students) } \\
\hline & \multicolumn{3}{|c|}{ Colleges } & \multicolumn{3}{|c|}{ Universities $^{1}$} & \multicolumn{3}{|c|}{ Total } \\
\hline Year & Public $^{1}$ & Private & Subtotal & Public $^{1}$ & Private & Subtotal & Public & Private & Subtotal \\
\hline 1990 & 27.0 & 296.9 & 323.8 & 444.4 & 836.3 & 1280.7 & 471.4 & 1133.1 & 1604.5 \\
\hline 1995 & 21.5 & 552.8 & 574.2 & 701.8 & 954.0 & 1655.8 & 723.3 & 1506.8 & 2230.1 \\
\hline 2000 & 37.3 & 877.0 & 914.3 & 834.2 & 1385.5 & 2219.8 & 871.6 & 2262.6 & 3134.1 \\
\hline 2005 & 36.2 & 820.4 & 856.6 & 798.2 & 1611.8 & 2409.9 & 834.3 & 2432.2 & 3266.5 \\
\hline 2010 & 21.5 & 751.1 & 772.5 & 787.6 & 1767.4 & 2555.0 & 809.1 & 2518.5 & 3327.5 \\
\hline $\begin{array}{l}\text { Share of } \\
\text { increase }\end{array}$ & -0.3 & 26.4 & 26.0 & 19.9 & 54.0 & 74.0 & 19.6 & 80.4 & 100.0 \\
\hline \multicolumn{10}{|c|}{ B. Change in the number of institutions } \\
\hline & \multicolumn{3}{|c|}{ Colleges } & \multicolumn{3}{|c|}{ Universities $^{1}$} & \multicolumn{3}{|c|}{ Total } \\
\hline Year & Public & Private & Subtotal & Public $^{1}$ & Private & Subtotal & Public & Private & Subtotal \\
\hline 1990 & 16 & 101 & 117 & 39 & 109 & 148 & 55 & 210 & 265 \\
\hline 1995 & 8 & 141 & 149 & 47 & 131 & 178 & 55 & 272 & 327 \\
\hline 2000 & 16 & 143 & 159 & 46 & 150 & 196 & 62 & 293 & 355 \\
\hline 2005 & 14 & 147 & 161 & 46 & 178 & 224 & 60 & 325 & 385 \\
\hline 2010 & 9 & 140 & 149 & 42 & 180 & 222 & 51 & 320 & 371 \\
\hline \multirow{2}{*}{$\begin{array}{l}\text { Share of } \\
\text { increase }\end{array}$} & & & & & & & & & \\
\hline & -6.6 & 36.8 & 0.9 & 2.8 & 67.0 & 69.8 & -3.8 & 103.8 & 100.0 \\
\hline
\end{tabular}

1. Includes education, industry, cyber and distance universities.

Source: Korea Educational Development Institute.

33. While overall spending at the tertiary level is the highest in the OECD area at $2.6 \%$ of GDP in 2009 , well above the OECD average of $1.6 \%$, the public sector accounted for only $26 \%$ of the total, around one-third of the OECD average (Figure 2). The government has focused its spending on primary and secondary education, leaving demand for tertiary education to be largely met by a self-financed private system. There is a significant difference in funding between public and private institutions. For national universities, the government provided $57 \%$ of financing, with tuition fees accounting for another $23 \%$. The picture is reversed for private universities: tuition fees account for about $67 \%$ of financing, with funds from the corporate sector providing most of the remainder (OECD, 2009). Government subsidies for public tertiary institutions amounted to 4.1 trillion won ( $0.4 \%$ of GDP) in 2008 (67 billion won per institution), compared to 2.4 trillion won for private tertiary institutions (6 billion won per institution). Nevertheless, the ratio of tuition fees at private universities relative to public ones fell from 2.1 in 2001 to 1.8 in 2010.

34. According to the 2009 OECD study, Korea "has developed a top-down system of control of universities and colleges", which tends "to limit opportunities for flexibility and innovation in private and national/public institutions". In particular, the government sets student admission quotas for the capital region and prohibits universities from giving their own entrance exams, forcing all potential students to take the CSAT. Other regulations govern the length and terms of educational programmes, the types of studies offered, rules on transfers, R\&D funds and procedures for appointing professors (OECD, 2009). In 
addition, the government regulates curriculum and grade management by setting school regulations for each university. Until 2007, university accreditation was delegated to private agencies.

35. Korea's university sector is not highly rated, in contrast to its primary and secondary schools, and it is widely acknowledged that rapid expansion has come at some expense to quality (OECD, 2009). Indeed, the World Competitiveness Yearbook ranks Korean universities, in terms of how well they meet the needs of a competitive economy, as the eighth lowest in the OECD in 2011, despite the high level of spending. In contrast, it ranks Korea's education system as a whole in the top half of OECD countries. Around $7 \%$ of Korean tertiary students study abroad, reflecting the higher value attached to foreign degrees. Weaknesses in the tertiary sector may reflect several factors. First, the increase in faculty has not kept pace with rising enrolments. Moreover, the share of part-time faculty has risen. Second, the quality of students has become much more diverse, as the share of students from vocational high schools in tertiary institutions has risen.

36. In contrast to the declining number of colleges and the leveling off in the number of universities, graduate education continues to expand rapidly in Korea. The number of students has more than tripled since 1990, reaching almost 320 thousand in 2010. Korea has more than 1100 graduate schools, of which about four-fifths are private institutions.

\section{Educational reforms to sustain economic growth}

37. This section discusses reforms from ECEC through the tertiary sector to promote output growth. In addition, it analyses measures to upgrade vocational education, at both the secondary and tertiary level, and to increase the role of the tertiary sector in innovation.

\section{Upgrade the quality of early childhood education and care}

38. ECEC plays an essential role in improving the educational development of children as well as increasing female labour force participation. Empirical work has established that fundamental cognitive and non-cognitive abilities are created well before the age of five. Investment in pre-primary education thus results in high rates of return, as it enhances later school achievement. However, total spending on pre-primary education per student in Korea in absolute terms was below the OECD average in 2009 (Figure 8). In addition, the public-sector share was only $43 \%$, compared with the average of $82 \%$ (Figure 2). Consequently, public expenditure on pre-primary education was the third lowest among OECD countries. Moreover, it is relatively low compared to spending at other levels of education; public outlays per student in kindergarten was only $42 \%$ of that in primary and secondary schools, well below the OECD average of $70 \%$.

39. The low level of spending on ECEC raises questions about its quality. Indeed, the PISA assessment found that participation in ECEC in Korea had the smallest impact among OECD countries on the educational achievement of 15-year-olds (OECD, 2010e). While the overall enrolment rate for children aged three to five is relatively high at $82 \%$, the ECEC enrolment pattern is not conducive to high quality. Indeed, the share in childcare (42.4\%), which has a weaker education orientation, is higher than the more academically-focused kindergartens (39.7\%). In recent years, the number of children in childcare has risen compared to declines in kindergarten, which face excess capacity. Moreover, about four-fifths of children are enrolled in private childcare facilities or kindergartens, which have lower quality than public institutions. Korea faces the intertwined problems of the low quality of childcare, a lack of places in higher-quality public centres and the affordability of childcare fees. The waiting lists for public childcare co-exist with significant excess capacity in private facilities. A range of policies would help improve the quality of ECEC. 
Figure 8. Spending per student on pre-primary education is low in Korea ${ }^{1}$

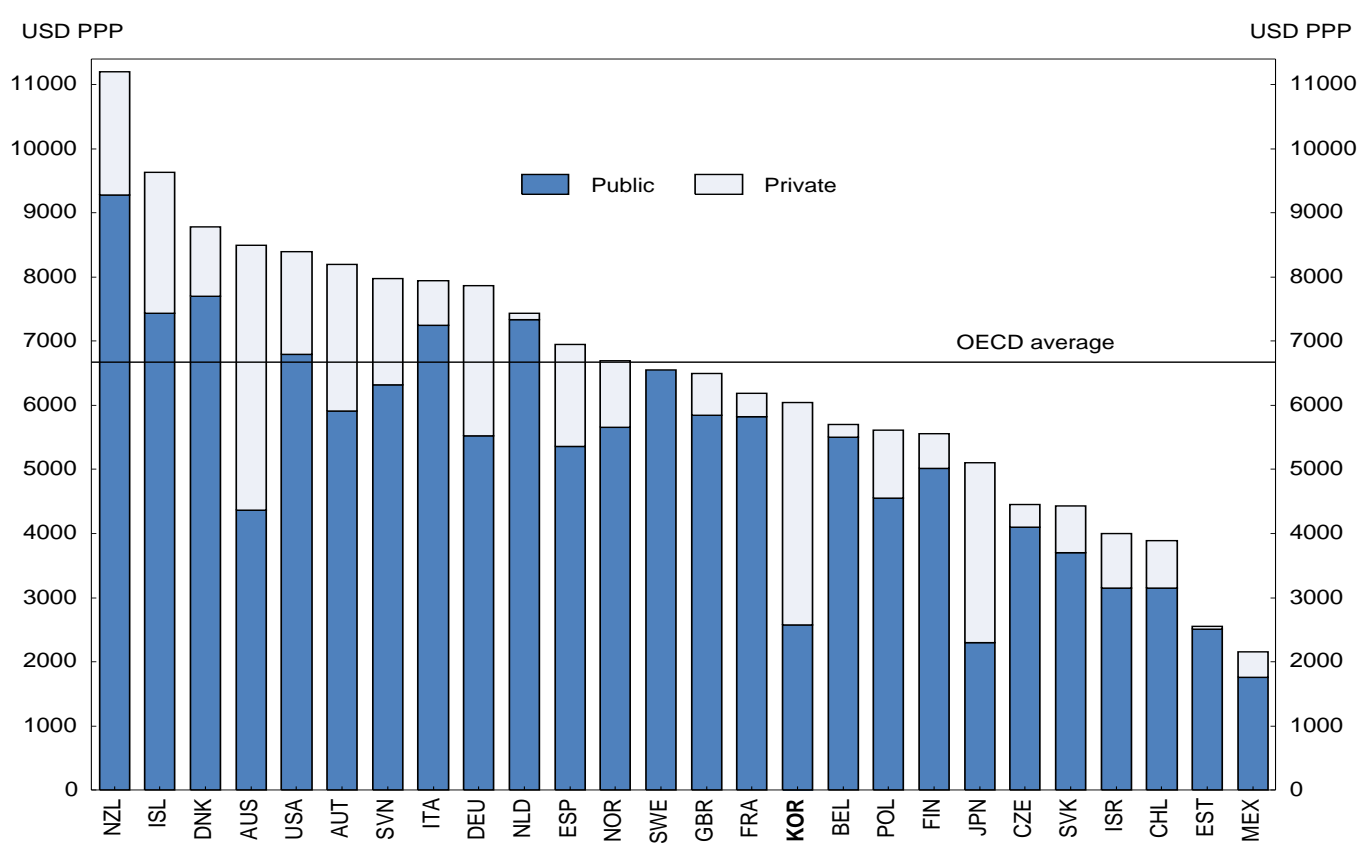

1. Annual outlays, in US dollars converted at purchasing power parity exchange rates, based on full-time equivalent students in 2009.

Source: OECD (2012b), OECD Education at a Glance 2012.

40. First, the growing share of childcare reflects the fact that it is cheaper than private kindergarten and private educational institutions known as hagwons, while there are waiting lists for public kindergarten. Raising tuition subsidies would improve access to private kindergarten. Over the medium term, adding more kindergartens to primary schools would expand capacity. The 2010 revision of the kindergarten law allows kindergartens to be attached to a primary or secondary school, but this is still rare in the capital region. The law should be revised to require new primary schools to include kindergartens.

41. Second, given that the expansion of kindergarten capacity will be gradual and insufficient to accept a significant share of the 0.6 million children aged three to five currently enrolled in childcare, it is important to upgrade the educational quality of childcare. The first step is to effectively implement the common curriculum for childcare and kindergarten, which began in 2012 for five-year-olds and extended to younger children in 2013.

42. Third, other measures are needed to upgrade the quality of childcare. One option would be to construct more public centres. For example, the mayor of Seoul, elected in 2011, promised to increase the number of public centres by about one-third to 848. However, the creation of 200 centres of average size would accommodate less than 14 thousand children, only slightly reducing enrolment in private childcare centres, which totals more than one million in Korea. ${ }^{13}$ Achieving higher-quality childcare will thus depend on ensuring consistent quality across the ECEC system by upgrading the quality of private centres. This would require stricter assessment and accreditation, given that around a quarter of private childcare facilities are not accredited by the government. Accreditation should be made mandatory, as a 2009 study

13. One option would be to absorb the private centres into the public sector, but this is opposed by the owners. 
reported that the quality of childcare centres improved after the accreditation process, especially for larger facilities (Suh et al., 2009). Moreover, the standards for accreditation should be made more stringent to strengthen parents' confidence in such centres. Finally, government tuition subsidies should be gradually limited to accredited childcare centres to promote quality.

43. Fourth, an upgraded accreditation system should be part of an effective information system on the quality of centres to help families make well-informed decisions. At present, the government discloses only the names of accredited centres, but not their scores or weaknesses, and parental awareness of the system is low. Enhancing transparency about quality would strengthen competition among centres.

44. Fifth, another key to higher quality is to raise the qualifications of teachers, particularly in private institutions. Raising the level of qualifications for teachers would help improve the quality of ECEC, while taking advantage of an under-utilised resource, given that around half of university graduates are unable to find regular employment.

45. Sixth, the fee ceilings imposed on private childcare providers are problematic. Private centres presumably wish to improve quality and attract children to fill their empty spaces, but have been blocked by the fee ceilings. Indeed, as noted above, the ceilings have been set below the level the government calculates to be necessary to provide adequate care (2008 OECD Economic Survey of Korea). The government should relax the price ceiling and entry barriers to upgrade the quality of private childcare centres. To ensure the affordability of childcare, the relaxation of fee ceilings could be accompanied by some increase in tuition subsidies for parents using accredited childcare centres.

46. Over the medium term, the quality of ECEC would be best promoted by further co-operation between childcare and kindergarten, culminating in their eventual integration. OECD work shows that a systematic and integrated approach to policy development and implementation delivers high-quality ECEC services (OECD, 2006). A number of OECD countries have integrated ECEC under one lead ministry, while others have been integrating services at the local level. Integration is not an end in itself, but instead a means to achieve better outcomes to strengthen the educational capacity of childcare. In addition to improving quality, countries' reasons for integrating ECEC include increasing enrolments, promoting fairness and streamlining management by eliminating a dual approach. The development of separate childcare and kindergarten systems in Korea aiming at largely the same age cohort in the absence of comprehensive planning has led to substantial administrative and financial inefficiencies (Rhee et al., 2008). The integration of the two systems is essential to limit duplication, conflict and confusion, thereby cutting the administrative and overhead costs of running two parallel systems, in part by allowing them to be housed in the same facilities.

47. While initial efforts to promote integration in Korea in the 1990s failed (Rhee et al., 2008), gradual integration based on the following steps would improve ECEC:

- Establishing common administrative and delivery systems. In particular, kindergartens could be allowed to care for children under three so that they target the same age group as childcare.

- Harmonising the regulations, standards and procedures for establishing childcare and kindergartens, thus allowing new facilities to be set up as integrated ECEC centres.

- Integrating staff qualifications, education and teacher training to allow individuals to teach at either type of institution. At present, the training of childcare and kindergarten teachers is compartmentalised in different institutions with different programmes. The best option would be to upgrade the qualifications for childcare staff to those required for kindergarten teachers. In addition, there is a sharp divide between the training of ECEC and primary school teachers. 
- Creating a common quality assurance mechanism.

- Establishing a coherent financing system that is fair (Rhee et al., 2008).

\section{Improve the quality of primary and secondary schools through greater autonomy and diversity}

48. While Korea is a top performer in the PISA, there is significant scope to improve schools in Korea, as the heavy reliance on hagwons suggests that there are weaknesses that prompt parents to turn elsewhere. It is important to address such weaknesses rather than relying on hagwons, with their associated costs and negative implications for equity (see below). To improve schools, the emphasis should be placed on greater local autonomy, expanding the scope for school choice at the primary level and increasing the diversity of institutions at the high school level. It is also important to adjust spending in the primary and secondary levels in line with falling enrolments. Although the number of students declined by $9 \%$ between 2000 and 2010, spending increased from $4.0 \%$ of GDP to $4.2 \%$ in 2008 , reflecting a $12 \%$ rise in the number of schools and a $22 \%$ increase in the number of teachers (Figure 9). Looking ahead, the number of primary and secondary students is projected to fall further by a quarter by 2020 and by more than one-half by mid-century, requiring changes in spending priorities.

Figure 9. Trends in the number of schools and teachers during the past decade

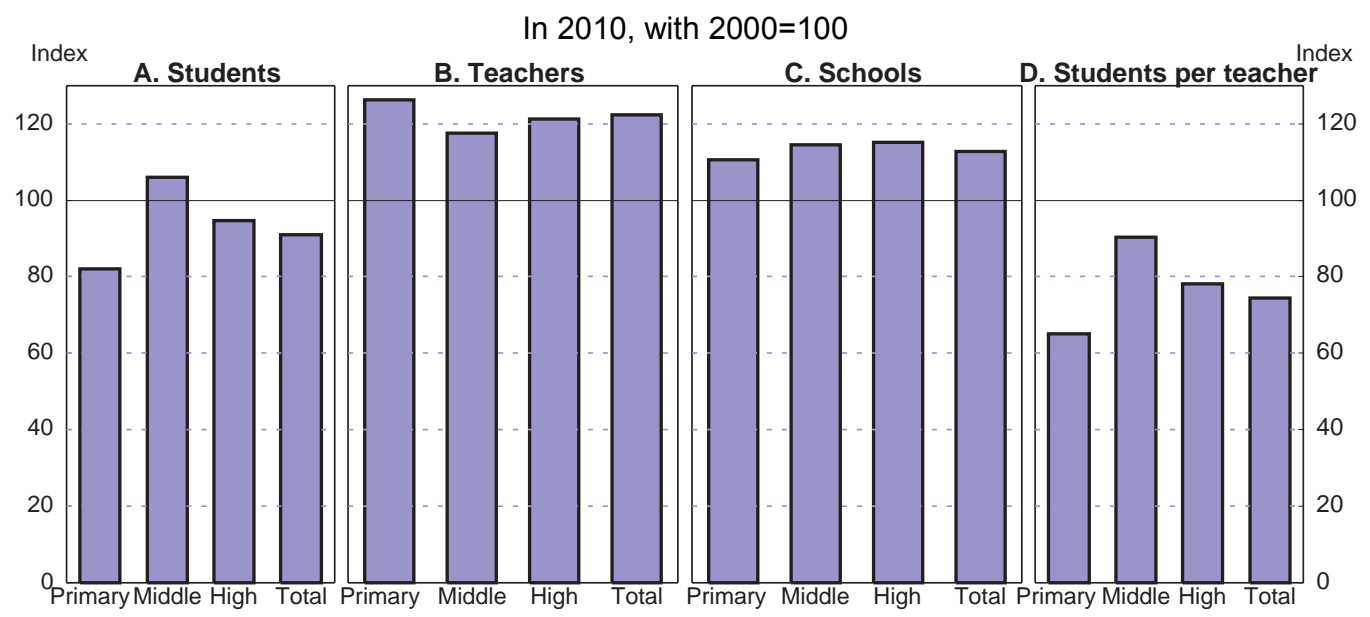

Source: Korean Educational Development Institute (2010).

\section{Autonomy and accountability}

49. OECD research demonstrates that educational performance is better in countries with greater decentralisation (Sutherland and Price, 2007). Moreover, a recent international study comparing 20 different school systems found that decentralisation was the key to turning good education systems into excellent ones (McKinsey, 2010). According to an OECD study, 46\% of decisions in middle schools in Korea are taken autonomously by the school or within a framework set by a higher authority, a share close to the OECD average (OECD, 2008b). The greatest autonomy was found in the "organisation of instruction" (78\%) and the lowest in "planning and structures" (25\%) and "personnel management" (42\%). Greater devolution of authority to schools would likely lead to better outcomes, given that Korea has made large strides in ensuring accountability. As noted above, schools' performance in the National Assessment of Educational Achievement and school evaluation reports have been publicly available since 2008 .

50. Increasing local funding of education and promoting closer integration of local education boards and offices of education with local general governments would enhance local autonomy in education. At 
present, the financing of local education authorities is provided primarily by central government grants, which are subject to central government rules and regulations. Shifting the taxes that provide education funding from the central to the local government level would increase local autonomy. Making local general governments more responsible for education would promote diversity, innovation and competition. This could be achieved, for example, by having the candidates for governor and education superintendent run as a team in elections. In the long run, merging the local education authorities with the local general government would provide many advantages.

\section{Expanding school choice}

51. School choice is not permitted in Korea at the primary and middle school level. Promoting competition among schools by allowing greater school choice has been found to improve educational outcomes in the OECD area (Sutherland and Price, 2007). In the 2009 PISA, competition and performance do seem related among schools within OECD countries, although the relationship weakens once the socio-economic profile of students is taken into consideration, as more privileged students are more likely to attend the best schools (OECD, 2010e). In the case of Japan, school choice at the primary level has been permitted on a limited scale since 2000, and several studies have shown positive results on educational outcomes. ${ }^{14}$ The success of school choice depends on the availability of publicly-provided information, which has been expanded in Korea, as noted above. While school choice is beneficial for individual schools, it is important to avoid negative externalities in other schools. Moreover, it is essential that school choice be accompanied by policies to ensure that financial costs or other factors related to changing schools do not limit the ability of low-income households to exercise school choice.

\section{Improve the quality of secondary schools through greater diversity}

52. The equalisation policy adopted in 1969 for middle schools and 1974 for high schools allocates students by lottery. While this was aimed at reducing the intense competition for school entry, one consequence has been weak competition and less diversification between schools, thereby reducing quality (Kim and Lee, 2003). The government launched the "300 High School Diversification Project" in 2008 to strengthen competition between schools and to increase diversity. Three new types of schools, which together will account for almost one-fifth of Korean high schools, have been introduced:

- Autonomous private schools are allowed significant autonomy in curriculum and management, in contrast to regular private schools. Although Korea has a large number of private schools, accounting for nearly one-fifth of middle school students and half of high school students, they follow the same curriculum and regulations as public schools, receive public funding and charge the same tuition fees as public ones. In contrast, the autonomous private schools, which do not receive government support, set tuition fees two to three times higher than for regular schools. By 2010, there were 51 independent private high schools and the number is to be increased.

- Meister schools, which emphasise workplace training, have been established to strengthen vocational education, based on the German model of training master craftsmen. Thus far, 28 Meister schools have been designated and the government hopes to increase the number. However, such schools are expensive as they are heavily subsidised by the government and require an agreement between the local government, the local school board and companies.

14. One study found that the university advancement rate of students in public schools in urban areas is higher in districts allowing school choice, with no negative effect on rural schools (Akabayashi, 2006). Another study found that school choice improved academic results, while between-school differences have not risen (Yoshida et al., 2009). 
- Special purpose high schools focus on certain subjects, such as science, foreign languages and the arts (MEST, 2010). By 2011, 99 specialised high schools had been created, accounting for $2.7 \%$ of high school students. Tuition is three times higher than at general high schools.

Admission to the autonomous and specialised high schools is based on the lottery system, in line with the equalisation policy. However, given their higher tuition, it is important to provide financial aid to ensure access for low-income students to make sure that the diversification of high schools does not create inequality.

\section{Upgrade the tertiary sector}

53. The development of human resources through tertiary education needs to be exploited fully in the face of demographic trends and competitive pressures. The government has increased support to colleges, primarily two-year institutions that still account for almost a quarter of tertiary students despite shrinking enrolments since 2000. The public share of their funding was doubled from $6 \%$ in 2005 to $12 \%$ in 2009 . In addition, the government is reducing its intervention in colleges, such as regulations on curriculum, to increase their autonomy so that they can quickly respond to changing economic and social conditions. However, more autonomy should be accompanied by higher quality standards. First, colleges should be required to meet a carefully-defined set of standards, including output indicators, such as labour market outcomes. Second, workplace training, which is currently optional and subject to weak quality control, should play a larger role to the extent possible. Third, employers should be more involved in vocational education, for example, by including them in colleges' boards of directors.

54. As noted above, it is widely acknowledged that the rapid expansion of Korea's university sector has come at some expense to quality (OECD, 2009). Korea is now in the process of shifting the focus from quantity towards quality and from inputs to outcomes through the Brain Korea 21 (BK21) programme and the World Class Universities initiative. International ratings suggest some progress: the number of Korean universities in the top 200 in the QS international rankings increased from two in 2007 to five in 2010. These initiatives, though, focus primarily on elite institutions. Quality concerns are a major issue at lowerranking universities and colleges. Governance reform, in part to enhance transparency, incorporation to promote autonomy, reducing public funding to poorly-performing universities and internationalisation are keys to strengthening competition and improving performance.

\section{Governance reform and transparency}

55. The government introduced a new quality management system for tertiary institutions in 2007 . First, universities were required to conduct self-evaluation of their education and research activities and publicly disclose the results, making them more responsible for quality. Second, it introduced a government recognition system for external assessment and accreditation agencies. The 2009 OECD study of Korea's university system criticised the previous accreditation system for its lack of coherence and rigour and the weak independence of the responsible organisations. To improve the accreditation process, the government selected two non-profit organisations as accreditation bodies for colleges and universities. Although accreditation is not mandatory, most universities are expected to participate because accreditation results will be publicly disclosed and linked to government funding programmes beginning in 2014. Accreditation should be made effective based on criteria including output measures, such as the employment of graduates, and evaluations by the business sector.

56. An effective accreditation system would facilitate a shift from a system of top-down, direct regulation, aimed at part in enforcing quality standards, to a more flexible approach. According to the OECD's 2009 study, "Korea has developed a top-down system of control of universities and colleges, and despite efforts to accommodate differences among institutions, this tends on the whole to limit 
opportunities for flexibility and innovation in private and national/public institutions". The objective should be to motivate universities to improve quality through innovation rather than regulations that enforce uniformity. During the past three years, many regulations governing such areas as student quotas, admission criteria and tuition fees have been abolished to strengthen universities' autonomy and promote flexibility and responsiveness to changing conditions. The government should continue to aim at improving quality rather than constraining behaviour and more at informing stakeholders than enforcing rules.

57. The new quality management system should enhance transparency and competition between universities, thereby improving quality. A website (http://www.academyinfo.go.kr) provides information on graduation rates and employment rates of graduates to help students make rational choices. However, more detailed data for specific departments would be useful in helping to better inform student decisions. In addition, it would disrupt the single array of university ratings that drives the competition among high school students to enter the highest-ranking universities. For universities, rather than trying to compete across the board with elite institutions, they could attract students by achieving excellence in certain fields.

\section{Incorporation of national universities}

58. Seoul National University (SNU), Korea's premier institution of higher learning, was incorporated in December 2011. Previously, SNU had been a government entity, subject to strict regulations on its employment, budget and operations, thus restricting its competitiveness. Incorporation will shift governance to the Board of Trustees and allow the university to have autonomy in personnel management, now that professors are no longer civil servants. The selection of the university president will shift from election by the faculty to recruitment by the Board (Rhee, 2007b). SNU will also gain autonomy over its budget, which in the past was provided on a line-item basis, and it will be allowed to choose various funding methods, such as long-term loans or issuing university bonds. Moreover, it will be able to exercise ownership rights over its assets, which are considerable. Increased autonomy is accompanied by greater responsibility for performance. SNU will set outcome goals with the government and be evaluated on its success in achieving them. The government believes that incorporation will help make SNU one of the world's most prominent universities. Most national universities oppose incorporation, preferring government status over more independence. Nevertheless, if this initial experiment proves successful in raising educational quality at $\mathrm{SNU}$, incorporation should be applied to other universities.

\section{Reducing funding to low-performing tertiary institutions}

59. Korea is a country with too many tertiary institutions and those outside of Seoul already have difficulty in filling their student quotas (OECD, 2009). All but a handful ran operating deficits between 2005 and 2008 (McNeil, 2011). Demographic projections suggest that the number of high school graduates will fall below the current admission quotas for tertiary institutions by the end of the decade. By 2030, the university-age cohort will be one-third below its 2010 level, according to the government's population projection. To induce voluntary restructuring of insolvent universities, the government provides subsidies for amalgamation, reveals financial information about weak universities and reduces their student quota. Thus far, M\&As have merged 23 private universities into 11, making only a small impact on the sector, which numbers 180 institutions. In 2010, the government consulted with 57 private universities, reduced admission quotas by 3000 students (only $0.1 \%$ of the total) and limited loans to students in 23 universities. The government is revising relevant laws to create an institutional exit for private institutions so that they can go through voluntary liquidation. The non-profit status of colleges and universities complicates M\&As, suggesting that at least a temporary change in their status would facilitate restructuring. Finally, providing adequate information through an accreditation and quality assurance system is essential to ensure that downsizing results in the restructuring, merger and closure of the weakest institutions. As for national universities, 20 have been consolidated into ten. 
60. However, these measures have been too weak to prompt a significant degree of consolidation in the tertiary sector. Beginning in 2012, the government has reduced public support to institutions that perform poorly. A committee of 20 experts evaluates tertiary institutions each year based on eight criteria, including employment rates of students after graduation, how well institutions fill their student quotas and their tuition increase rate. The committee identifies the bottom 15\% (about 50 private institutions), which are not eligible for project-based or institutional-level grants during the following year. In addition, loans to students at some of these institutions that fail to meet additional evaluation requirements are restricted, ${ }^{15}$ but not scholarships and grants. ${ }^{16}$ While these institutions are largely funded by tuition payments, the stigma of being classed in the lower $15 \%$ is expected to prompt management changes in order to earn a higher ranking the following year. Some universities, though, have complained that uniform standards, such as for employment rates, do not adequately take account of the characteristics of some universities, such as art schools (Joongang Daily, 1 October 2011).

\section{Internationalisation of the university sector}

61. The university system has only a limited degree of internationalisation, as reflected in the relatively low number of students from overseas and a near absence of foreign higher education institutions operating in Korea. The share of foreign students in tertiary education in Korea in 2009 was only 1.6\%, well below the OECD average of $8.7 \%$, although the number has increased rapidly since 2000 . In contrast, Korea was the largest source of foreign students in OECD countries, accounting for 5\% of the total in 2009. These students amount to about $7 \%$ of Korean tertiary students. Attracting foreign students to Korea would upgrade the quality of tertiary education, in addition to providing high-skilled human resources for Korea. Moreover, it would help mitigate the severe financial situation of tertiary institutions in Korea. For these reasons, the government established the "Study Korea Project Plan" in 2008, with a target of attracting 100 thousand foreign students by 2012 by improving the competitiveness of higher education. To this end, the government is expanding exchanges of students and faculty, facilitating joint research among universities, and running a cross-border joint degree system through the Campus Asia programme with China and Japan. In 2011, the government introduced the Accreditation System on Recruitment and Support of International Students in order to better attract and assist outstanding foreign students and improve the quality of education. Policies to attract outstanding students to leading graduate schools should be strengthened, rather than simply recruiting foreign students to fill empty chairs as Korea's university-age population declines. The competition is severe as other Asian countries have similar targets to attract foreign students, including Japan ( 300 thousand by 2020), China (500 thousand by 2020) and Singapore (150 thousand by 2015).

62. Facilitating the entry of accredited foreign institutions would also stimulate competition and upgrade the competitiveness of universities. At present, there are only three foreign universities operating in Korea, ${ }^{17}$ as some regulations to ensure the quality of education and to protect consumers, such as standards for setting up campuses (buildings and property), act as entry barriers. In addition, the non-profit juridical person requirement for schools discourages the entry of foreign educational institutions by prohibiting them from remitting profits.

15. Students attending schools in the "minimum loan" group can only borrow $30 \%$ of their tuition, while those in the "limited loan" group can borrow $70 \%$.

16. However, new students attending the bottom $15 \%$ of universities will face restrictions on receiving the new national scholarships that were introduced in 2012 to reduce tuition fees.

17. These include the Shipping \& Transportation College from the Netherlands, Friedrich-Alexander University of Germany and Stony Brook of New York State University. 


\section{Improve vocational education to address the overemphasis on tertiary education}

63. There are complaints from the business sector about a lack of skills among new graduates. For example, the Korea Employers' Federation estimates that it takes 30 months and \$100 thousand on average to train new graduates. Another study estimated that the average length of training for university graduates is 8.4 months, with the length increasing with the size of the company (KRIVET, 2007). Upgrading vocational education is important to boost labour productivity.

64. At the same time, it would help Korea address its problem of overemphasis on tertiary education. Even in 2007 - with real output growth of $5.1 \%$, a $1.2 \%$ rise in employment and an unemployment rate of $3.2 \%$ - only $51.9 \%$ of university graduates were able to find regular jobs in the year following graduation (Table 10). Another $16.1 \%$ accepted non-regular jobs, primarily in temporary positions. While some graduates were enrolled in graduate school or fulfilling their military service obligation (21 months), $20.5 \%$ were not working. In 2009 , around $25 \%$ of youth with tertiary education were neither in employment nor in education, the second-highest share in the OECD area and double the OECD average (Figure 10). Moreover, the rate is higher for tertiary graduates in Korea than for those with high school education, in contrast to most other OECD countries. Among those who remain in the labour force, $40 \%$ of tertiary graduates spent more than three months to find their first job. In addition, a growing number of graduates do not find employment corresponding to the skills they acquired in education. For example, about $40 \%$ of university graduates in natural and social sciences do not find jobs in their field of study (OECD, 2009).

Table 10. Employment outcomes for university graduates in 2007

\begin{tabular}{|c|c|c|c|c|c|c|c|c|c|c|}
\hline & \multirow[t]{2}{*}{ Graduates } & \multirow[t]{2}{*}{ Employed } & \multirow[t]{2}{*}{ Regular } & \multicolumn{4}{|c|}{ Non-regular employees } & \multirow{2}{*}{$\begin{array}{c}\text { Self- } \\
\text { employed }\end{array}$} & \multirow{2}{*}{$\begin{array}{c}\text { Not } \\
\text { working }\end{array}$} & \multirow[t]{2}{*}{ Others ${ }^{4}$} \\
\hline & & & & $\begin{array}{l}\text { Sub- } \\
\text { total }\end{array}$ & $\begin{array}{l}\text { Tempo- } \\
\text { rary }\end{array}$ & Daily ${ }^{2}$ & Family $^{3}$ & & & \\
\hline \multirow[t]{2}{*}{ Total } & 560632 & 390180 & 290907 & 90470 & 60749 & 26633 & 3088 & 8803 & 115073 & 55379 \\
\hline & & $69.6 \%$ & $51.9 \%$ & $16.1 \%$ & $10.8 \%$ & $4.8 \%$ & $0.6 \%$ & $1.6 \%$ & $20.5 \%$ & $9.9 \%$ \\
\hline \multirow[t]{2}{*}{ Colleges } & 215040 & 173804 & 132783 & 37678 & 25248 & 11584 & 846 & 3343 & 27527 & 13709 \\
\hline & & $80.8 \%$ & $61.7 \%$ & $17.5 \%$ & $11.7 \%$ & $5.4 \%$ & $0.4 \%$ & $1.6 \%$ & $15.8 \%$ & $6.4 \%$ \\
\hline \multirow{2}{*}{$\begin{array}{l}\text { Teacher } \\
\text { universities }\end{array}$} & 5929 & 4109 & 3680 & 429 & 417 & 12 & 0 & 0 & 1537 & 283 \\
\hline & & $69.3 \%$ & $62.1 \%$ & $7.2 \%$ & $7.0 \%$ & $0.2 \%$ & $0.0 \%$ & $0.0 \%$ & $25.9 \%$ & $4.8 \%$ \\
\hline \multirow{2}{*}{$\begin{array}{l}\text { General } \\
\text { universities }\end{array}$} & 277858 & 168254 & 120618 & 44333 & 28644 & 13608 & 2081 & 3303 & 75842 & 33762 \\
\hline & & $60.6 \%$ & $43.4 \%$ & $16.0 \%$ & $10.3 \%$ & $4.9 \%$ & $0.7 \%$ & $1.2 \%$ & $27.3 \%$ & $12.2 \%$ \\
\hline \multirow{2}{*}{$\begin{array}{l}\text { Industrial } \\
\text { universities }\end{array}$} & 26490 & 19714 & 15701 & 3299 & 2425 & 737 & 137 & 714 & 5354 & 1422 \\
\hline & & $74.4 \%$ & $59.3 \%$ & $12.5 \%$ & $9.2 \%$ & $2.8 \%$ & $0.5 \%$ & $2.7 \%$ & $20.2 \%$ & $5.4 \%$ \\
\hline \multirow[t]{2}{*}{$\begin{array}{l}\text { Other } \\
\text { universities }\end{array}$} & 282 & 109 & 48 & 57 & 57 & 0 & 0 & 4 & 16 & 157 \\
\hline & & $38.7 \%$ & $17.0 \%$ & $20.2 \%$ & $20.2 \%$ & $0.0 \%$ & $0.0 \%$ & $1.4 \%$ & $0.5 \%$ & $55.6 \%$ \\
\hline \multirow[t]{2}{*}{$\begin{array}{l}\text { Graduate } \\
\text { school } \\
\text { (general) }\end{array}$} & 35033 & 24190 & 18077 & 4674 & 3958 & 692 & 24 & 1439 & 4797 & 6046 \\
\hline & & $69.0 \%$ & $51.6 \%$ & $13.3 \%$ & $11.3 \%$ & $2.0 \%$ & $0.1 \%$ & $4.1 \%$ & $13.7 \%$ & $17.2 \%$ \\
\hline
\end{tabular}

1. Temporary employees are those whose labour contracts are for less than one year.

2. Includes part-time employees who work more than 18 hours a week.

3. Family employees are unpaid workers in establishments owned by family or relatives.

4. Includes those continuing to advanced studies and men fulfilling their military service obligation.

Source: Ministry of Education, Science, and Technology. 
Figure 10. The share of inactive youth with tertiary education is high in Korea

The share of the 15-to-29 age group neither in employment nor in education in $2009^{1}$

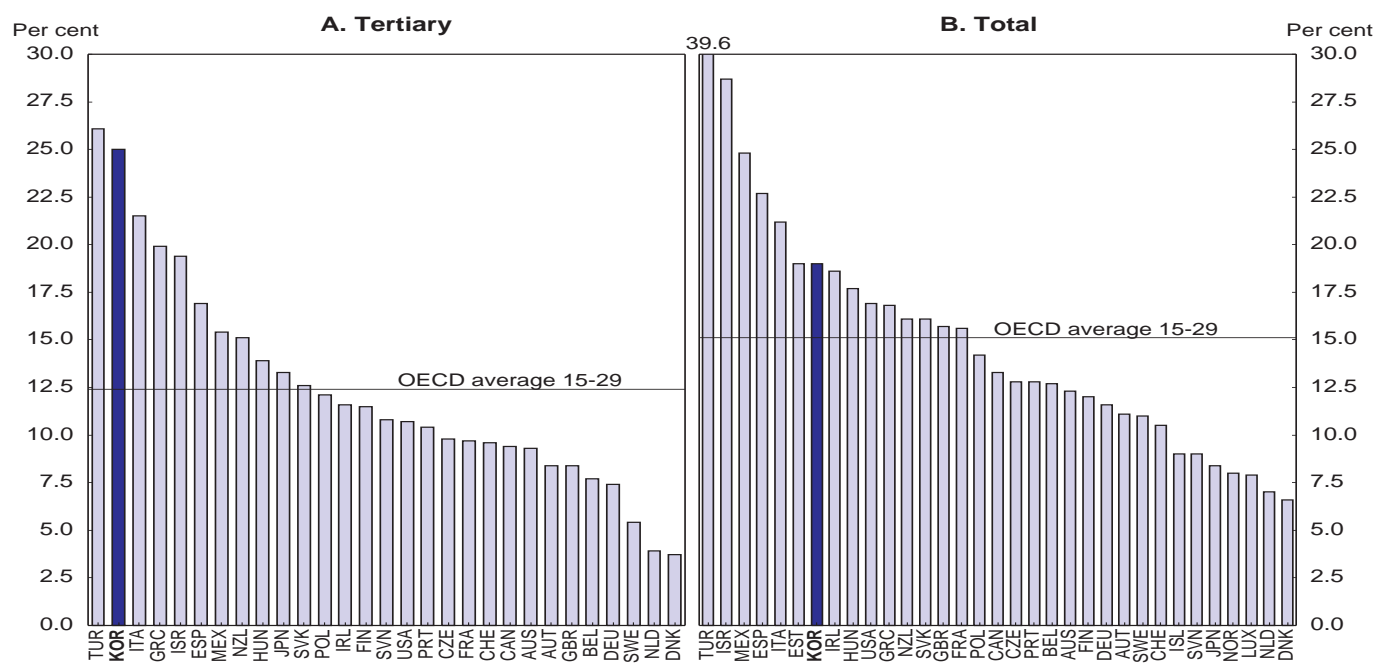

1. Data on the category ISCED 4, which captures programmes that straddle the boundary between upper secondary and postsecondary education, are not available in Korea and eleven other OECD countries. This category could potentially include persons in an apprenticeship or training outside of school. The numbers in the chart therefore overestimate the number of youth who are inactive in these countries.

Source: OECD (2011c), OECD Education at a Glance 2011 and Statistics Korea, Economically Active Population Survey.

65. The problem of overemphasis on tertiary education is evident in other aspects of the labour market. First, the employment rate for university graduates in the 25-to-64 age group in Korea was only 2.5 percentage points above the rate for the overall population in 2009, the smallest gap in the OECD area (Figure 11). Similarly, the unemployment rate for university graduates was almost identical to the overall unemployment rate, compared to an average 2.5 percentage-point gap in the OECD area. Second, the wage premium for tertiary graduates in Korea is relatively low: tertiary graduates earned only $43 \%$ more than high school graduates, as against an OECD average of 63\% (Panel B).

66. While university graduates are underused, small and medium-sized enterprises (SMEs) face labour shortages. In addition to creating mismatches in the labour market, the overemphasis on tertiary education imposes a huge financial burden on Korea. As former president Lee Myung-bak stated, "Reckless university enrolment has aggravated both the private education budget and youth unemployment. It's a huge loss, not just for households but the whole country" (Financial Times, 11 June 2011). As noted above, the share of GDP devoted to tertiary education - public and private - in 2009 was the highest in the OECD area at $2.6 \%$. In addition, much of the private education expense on after-school lessons, particularly at hagwons - another $2 \%$ of GDP - is focused on gaining admission to high-ranking universities. Addressing the problem of overemphasis on tertiary education is difficult as it is based on the national consensus that higher education is the key to success (Chang, 2009). A university degree has become the standard expectation, regardless of students' capabilities or career aspirations. It is necessary to gradually shift the focus from chasing the status and prestige of high-ranking universities to rewarding the acquisition of skills that are demanded in the labour market. In 2011, the government signed an agreement with five major business organisations that agreed to provide more job opportunities for high school graduates, especially from vocational schools. 
Figure 11. International comparison of labour outcomes for university graduates in $2009^{1}$

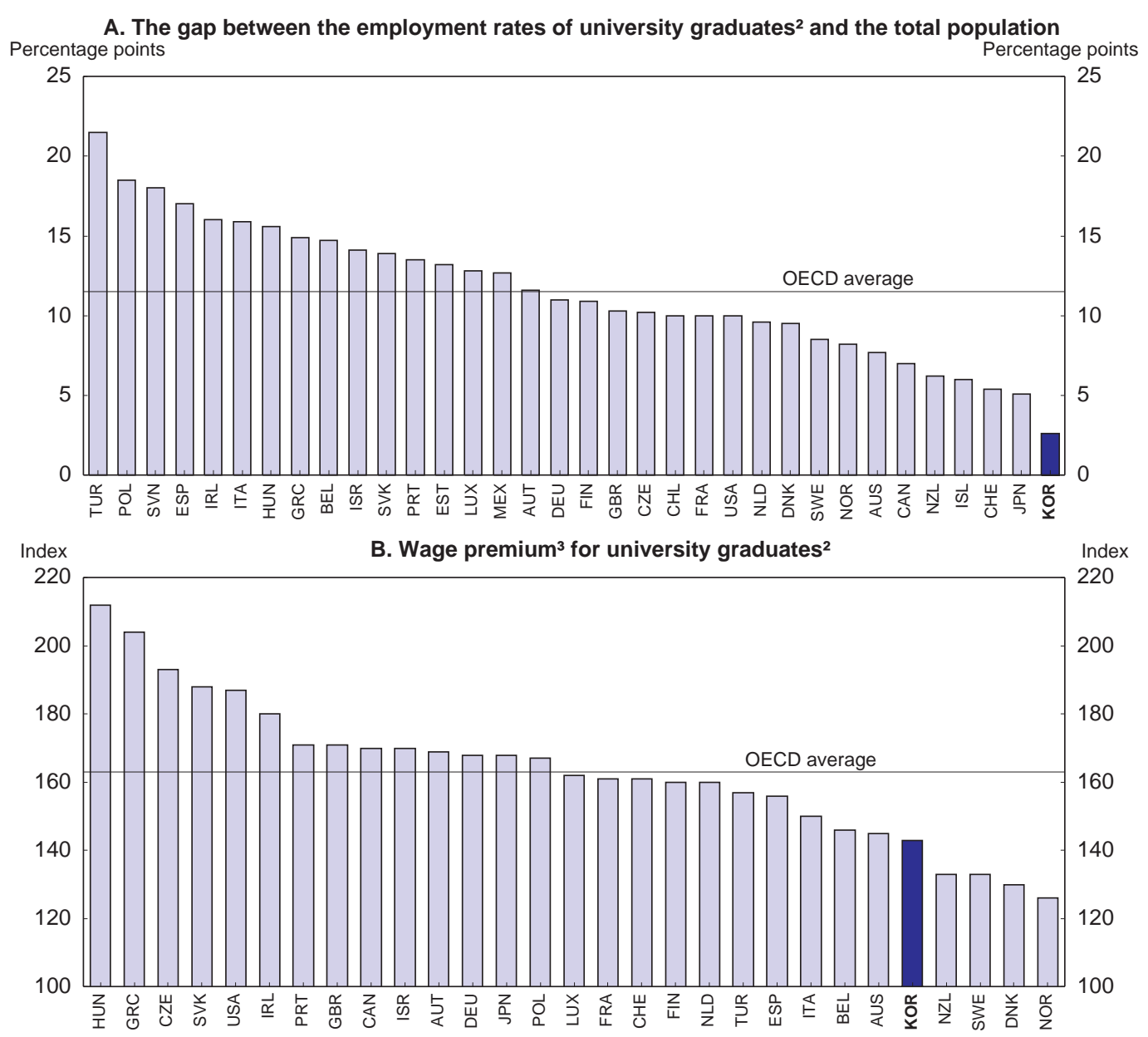

1. For the population between the ages of 25 and 64 .

2. Based on tertiary-type A programmes (ISCED 5A), which are largely theory-based and are designed to provide qualifications for entry to advanced research programmes and professions with high skill requirements, such as medicine and dentistry.

3. The wages of upper secondary and post-secondary non-tertiary graduates are set at 100 .

Source: OECD (2011c), OECD Education at a Glance 2011.

67. As noted above, following the 2008 global crisis, the share of high school graduates advancing to tertiary education fell to 72.5 in 2011 from its peak of $84 \% .{ }^{18}$ However, it is too early to say whether this is a permanent trend or a temporary response to the 2008-09 economic crisis. In any case, the share remains high. In order to reduce the blind pursuit of higher education, it is important to improve vocational education at both the secondary and tertiary level and demonstrate that it leads to favorable labour market outcomes. At the secondary level, vocational high schools' share of students has fallen sharply over the past 20 years, as noted above, reflecting the below-average academic achievement of their students. Moreover, despite the efforts of vocational high schools to keep up with changes in the industrial structure and technology, the range of occupations for which vocational high school graduates are qualified has fallen, resulting in continued mismatch problems (Park et al., 2010). A 2010 government survey suggests that the share of vocational schools is set to fall further: only $6.4 \%$ of the parents of middle school students

18. This primarily reflects a decline in the advancement rate from general high schools from $87.9 \%$ to $75.2 \%$ between 2008 and 2011, while the rate fell from $72.9 \%$ to $63.7 \%$, for vocational high schools. 
want their children to attend a vocational school, compared to $64.4 \%$ for general schools (Table 11 ). In contrast, independent private high schools are becoming increasingly popular.

Table 11. Preferences for high school by type of institution

Per cent of middle school students and their parents

\begin{tabular}{lccccccc}
\hline Year & General & Specialised & $\begin{array}{c}\text { Independent } \\
\text { private }\end{array}$ & $\begin{array}{c}\text { Artistic, } \\
\text { athletic }\end{array}$ & Vocational & $\begin{array}{c}\text { Within a } \\
\text { university }\end{array}$ & $\begin{array}{c}\text { Overseas } \\
\text { studies }\end{array}$ \\
\hline 2009 & 66.5 & 13.5 & 4.9 & 5.9 & 7.7 & 0.9 & 0.7 \\
2010 & 64.4 & 11.2 & 7.5 & 8.4 & 6.4 & 1.4 & 0.6 \\
\hline
\end{tabular}

1. Special purpose high schools that focus on certain subjects, such as science or foreign languages.

Source: Ministry of Education, Science and Technology (2011).

68. In 2010, the government introduced the "Plan for Enhancing High School Vocational Education" to improve vocational high schools and Meister schools through financial assistance and other support. The employment rate of vocational high school graduates increased from $19 \%$ in 2010 to $42 \%$ in 2012 . In addition, $81 \%$ of seniors in Meister schools have already signed employment contracts.

69. The role of colleges would also be enhanced by improving the system of qualifications. The two parallel systems of standards - "occupational standards" (managed by the Ministry of Employment and Labour) and "skills standards" (managed by the Ministry of Education) - have been united under the new "competency standards" and will be the basis for national technical qualifications (NTQ). At present, vocational programmes do not systematically reflect occupational standards and the courses do not lead to the qualifying exams. Instead, students typically have to prepare separately for those exams. Moreover, Korea still has thousands of private-sector qualifications established by companies and training institutes. It is important to converge towards a core set of standards, taking into account private-sector views, in order to include the skills that they value. Such an approach would allow college courses, as well as those offered by vocational high schools, to be aligned with the NTQ requirements and prepare students for the NTQ exams. Moreover, making it possible to take an NTQ exam without completing a college programme would further reduce unnecessary tertiary education.

70. Other policies would enhance the role of the two-year colleges in competing against universities, which have been gaining students by encroaching on the vocational territory of colleges. First, the government should introduce policies to discourage universities from entering fields that are more appropriately handled at the college level to stop such "institutional drift". For example, some lower-quality universities now offer four-year programmes in cosmetology, which are surely jobs that should be filled by college or secondary school graduates (OECD, 2009). Second, improving co-ordination between colleges and universities would help to lessen the stigma of colleges by making them a stepping stone to university. Only $6 \%$ of college graduates enter a university programme and they are poorly prepared as there is little co-ordination of curricula between the two systems.

71. Labour market reforms to break down dualism would also help resolve the problem of overemphasis on tertiary education. Tertiary graduates accounted for $53.6 \%$ of regular workers in 2011 , but only $31.5 \%$ of non-regular workers. Students know that a tertiary degree enhances their chance of finding regular employment, which offers higher salaries, greater job stability and better coverage by the social safety net. Breaking down dualism would reduce this incentive for higher education. More generally, increasing the weight of performance in determining wages - while reducing that of education and seniority - would better reward the skills acquired in education and reduce the motivation for tertiary education. 


\section{Expand the role of the education system in innovation}

72. Korea's gross domestic expenditure on R\&D (GERD) amounted to 3.7\% of GDP in 2010, well above the OECD average of $2.4 \%$ and the third highest in the OECD. The "577 Initiative" targeted an increase in GERD to 5\% of GDP in 2012 to make Korea one of the "seven major science and technology powers in the world" (MEST, 2009).${ }^{19}$ The government supports private R\&D through direct funding and tax incentives, which together provide the largest support for R\&D after France in the OECD area. Business enterprises accounted for $71.8 \%$ of $R \& D$ funding and performed $74.8 \%$ of $R \& D$ in 2010 (Table 12), the third-largest share in the OECD area (Figure 12). In contrast, universities accounted for only $0.9 \%$ and $10.8 \%$, respectively, the lowest in the OECD area, despite the fact that Korea's share of articles in the Science Citation Index doubled from 1.3\% in 1999 to $2.5 \%$ a decade later, the $11^{\text {th }}$-highest in the world. Korea also stands out for its low degree of internationalisation in R\&D: it ranks as fourth lowest in the OECD measure of international collaboration among institutions (OECD, 2011d).

Table 12. Flows of R\&D funds in $\mathbf{2 0 1 0}$

\section{A. R\&D Funding}

\begin{tabular}{lc|rrr}
\hline & \multicolumn{2}{c}{ Allocation between R\&D actors $^{2}$} \\
\cline { 2 - 5 } & $\begin{array}{c}\text { Share of total R\&D } \\
\text { spending }\end{array}$ & Government & Universities & $\begin{array}{c}\text { Business } \\
\text { enterprises }\end{array}$ \\
\cline { 2 - 5 } Government & 27.1 & 49.0 & 32.3 & 18.6 \\
Universities & 0.9 & 4.8 & 91.4 & 3.7 \\
Business enterprises & 71.8 & 1.4 & 1.7 & 96.9 \\
Foreign sources & 0.2 & 26.4 & 21.1 & 100.0 \\
\hline
\end{tabular}

B. Sector performing R\&D

\begin{tabular}{|c|c|c|c|c|c|c|}
\hline & \multicolumn{6}{|c|}{ Funding source for R\&D performed } \\
\hline & $\begin{array}{c}\text { Share of total } \\
\text { R\&D } \\
\text { performed }\end{array}$ & Government & Universities & $\begin{array}{l}\text { Business } \\
\text { enterprises }\end{array}$ & $\begin{array}{l}\text { Foreign } \\
\text { sources }\end{array}$ & Total \\
\hline Government ${ }^{1}$ & 14.4 & 92.5 & 0.3 & 6.8 & 0.4 & 100.0 \\
\hline Universities & 10.8 & 81.1 & 7.2 & 11.3 & 0.4 & 100.0 \\
\hline Business enterprises & 74.8 & 6.8 & 0.0 & 93.1 & 0.2 & 100.0 \\
\hline
\end{tabular}

1. Includes private non-profit institutes.

2. By which sector performs the R\&D.

Source: OECD R\&D Statistics Database.

73. Increasing the effectiveness of $R \& D$ requires expanding the interaction between researchers in business, government and universities (Baek and Jones, 2005). In 2010, 96.9\% of the R\&D financed by enterprises was performed by enterprises and only $1.7 \%$ at universities (Table 12), which employ around three-quarters of the PhDs in Korea. Despite relatively low wages, universities attract researchers because of the high level of social respect accorded to professors and job security, in contrast to business research centres. The weak links between R\&D in firms and universities may reflect the concentration of firms in applied research. However, as Korea has reached the technology frontier in many areas, the importance of basic research - typically concentrated in universities - should play a growing role. Given that the transfer of knowledge and technology takes place to a large extent through people, it is important to promote the mobility of researchers by expanding the use of fixed-term contracts and performance evaluation at

19. The Initiative also set the objective of boosting basic research from $26 \%$ of government R\&D to $50 \%$ by 2012. At the same time, it is to focus on seven major technology areas, including cars, shipbuilding, machinery and semiconductors. 
universities and by requiring young researchers to change their organisational affiliation at least once after graduation before obtaining a permanent position. Finally, the share of government R\&D funding for universities that is allocated competitively should be increased.

Figure 12. R\&D expenditure by performing sector

As a per cent of gross domestic expenditure on R\&D in 2011 or latest year available

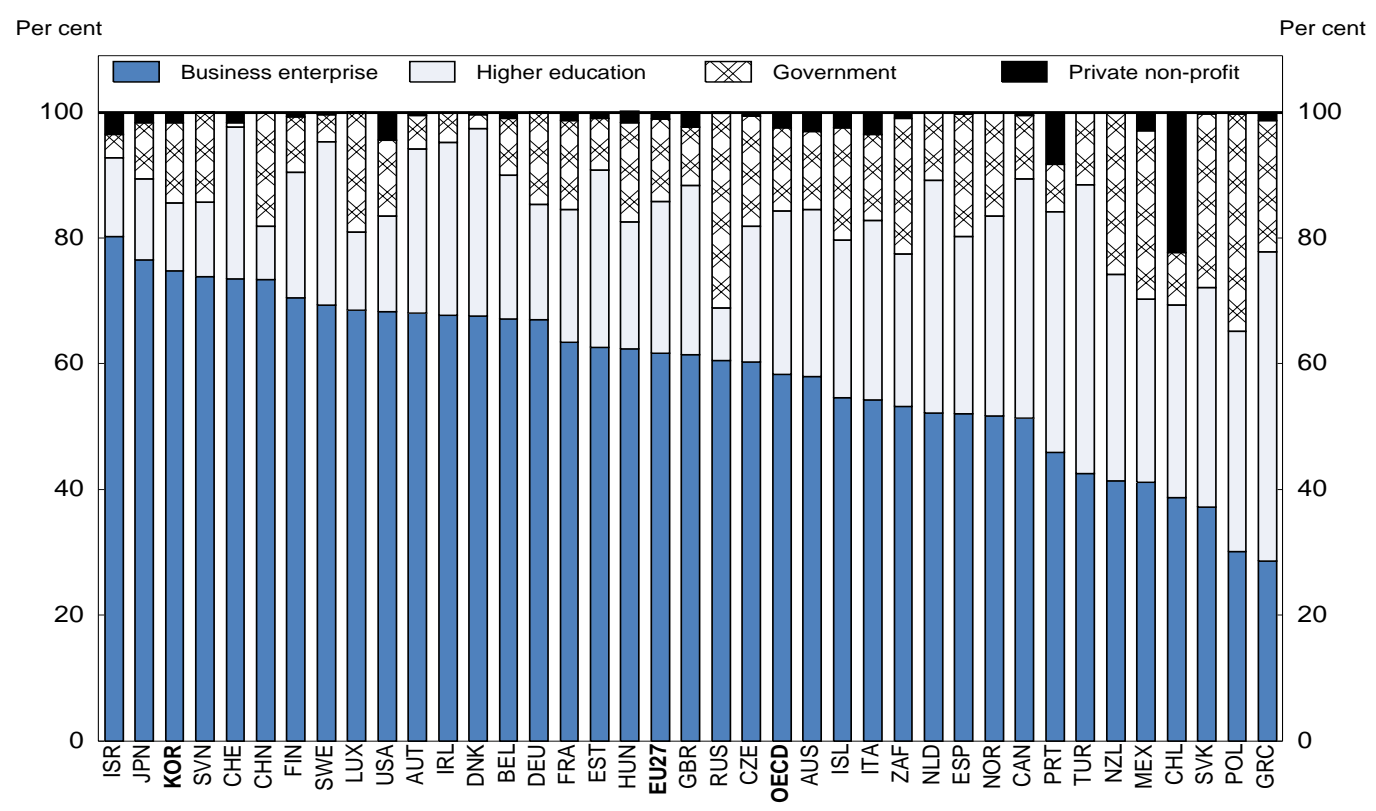

Source: OECD Main Science and, Technology Indicators Database.

\section{Educational reforms to promote social cohesion}

74. In addition to boosting economic growth, the emphasis on universal access to primary and secondary schools promoted social mobility and income equality (Koh et al., 2010). However, some aspects of the education system today should be improved, given that policies that promote equal access to education help reduce inequality (OECD, 2012a). First, greater investment in ECEC would provide a better educational foundation for children from low-income households. Second, the widespread use of private tutoring, notably in hagwons, perpetuates inequality. Third, the low level of student loans and grants despite high tuition fees limits the access of students from low-income households to high-quality tertiary education. This section discusses reforms in each of these areas to improve equity. Policies to address these issues would also help reduce the heavy financial burden on families. Households accounted for $27 \%$ of spending on educational institutions in 2009, the second highest in the OECD area, even before taking account of outlays for hagwons (Figure 13). In comparison, households' share was only 8\% in EU countries.

\section{Improving access to high-quality early childhood education and care}

75. As noted above, spending in pre-primary education in Korea was below the OECD average in 2009, reflecting a low level of spending by the public sector (Figure 8). Indeed, public spending on childcare amounted to $0.4 \%$ of GDP, below the OECD average of $0.6 \%$. Since 1991, the government has provided means-tested subsidies to defray the cost of ECEC (Box 1). Most families receiving the meanstested subsidies send their children to childcare centres, even though it has a weaker educational orientation, reflecting several factors: $i$ ) they are considerably cheaper than private kindergarten, whose 
basic fees run as high as three times the government subsidy, which is based on public childcare; ii) there is a lack of capacity in public kindergartens; iii) childcare centres tend to be more conveniently located because there are more than four times as many childcare centres as kindergartens; and $i v$ ) they are more convenient for working parents as they have longer hours and stay open year-round, in contrast to kindergartens, which operate about 180 days a year. As a result, families at lower socioeconomic levels and working mothers tend to resort to childcare, while middle and upper-income families tend to place their children in kindergarten (Yun, 2009), thus perpetuating inequality.

\section{Figure 13. Households' share of spending on educational institutions is high in Korea ${ }^{1}$}

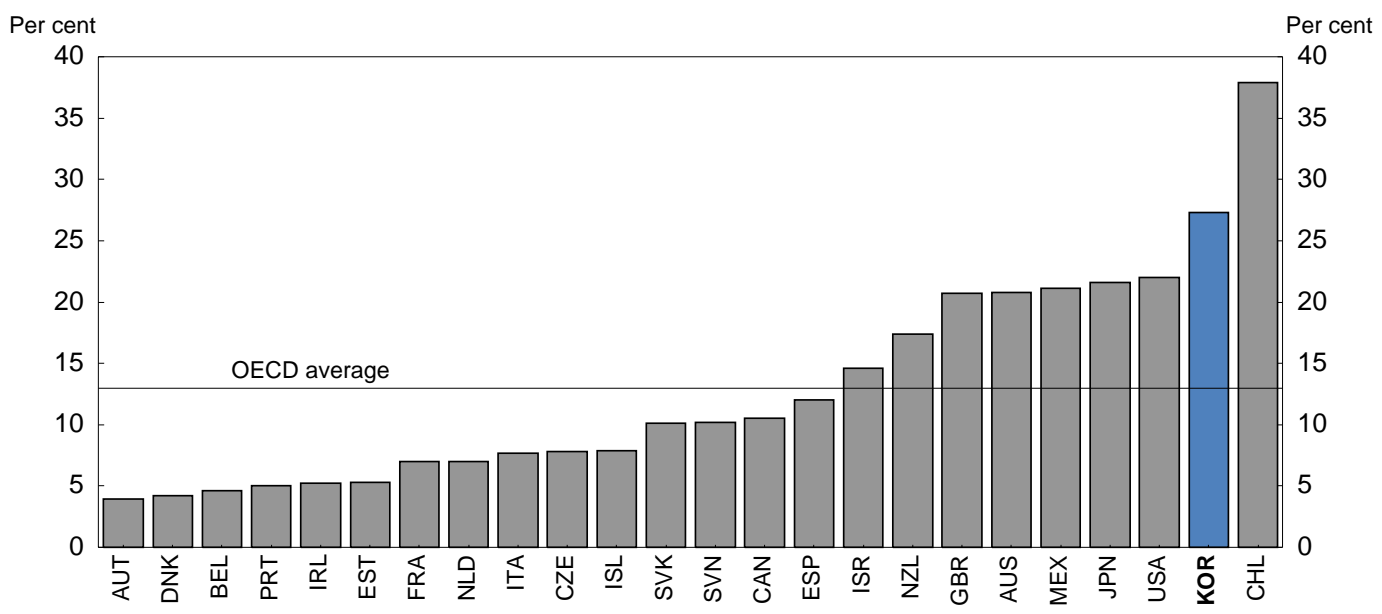

1.

In 2009. Excludes spending on private, after-school tutoring.

Source: OECD (2012b), OECD Education at a Glance 2012.

\section{Improving access to high-quality early childhood education and care}

76. As noted above, spending in pre-primary education in Korea was one-third below the OECD average in 2009, reflecting a small level of spending by the public sector (Figure 8). Indeed, public spending on childcare amounted to $0.4 \%$ of GDP, below the OECD average of $0.6 \%$. Since 1991 , the government has provided means-tested subsidies to defray the cost of ECEC (Box 1). Most families receiving the means-tested subsidies send their children to childcare centres, even though it has a weaker educational orientation, reflecting several factors: $i$ ) they are considerably cheaper than private kindergarten, whose basic fees run as high as three times the government subsidy, which is based on public childcare; ii) there is a lack of capacity in public kindergartens; iii) childcare centres tend to be more conveniently located because there are more than four times as many childcare centres as kindergartens; and $i v$ ) they are more convenient for working parents as they have longer hours and stay open year-round, in contrast to kindergartens, which operate about 180 days a year. As a result, families at lower socioeconomic levels and working mothers tend to resort to childcare, while middle and upper-income families tend to place their children in kindergarten (Yun, 2009), thus perpetuating inequality.

77. Higher-income families also tend to enrol their pre-primary age children in hagwons. Indeed, Seoul and surrounding Gyeonggi province, which have the largest number of hagwons, have among the lowest enrolment rates for both childcare and kindergarten. However, hagwons provide an average of only five hours of class a day, and no full-day service is available, making them less advantageous for dualincome families. Consequently, the share of working mothers among the children attending hagwons is low compared to childcare and kindergartens (Table 2). 
78. The increasing importance of hagwons reflects intense academic competition beginning at a young age. Indeed, providing "differentiated programmes to help distinguish one's children from other children" was the main reason, cited by nearly half of parents in a survey in Seoul and Gyeonggi, for enrolling children in hagwons rather than childcare and kindergarten (Lee et al., 2009).The popularity of hagwons stems in part from the zeal to have children learn English at a young age. As a result, hagwons are sometimes called "English kindergartens". According to a recent survey, the average age for beginning English classes is 3.7 in Seoul and Gyeonggi province, with some children beginning before age two (Korea Herald, 30 August 2011). The study found that the higher the mother's level of education, the younger the age at which children begin learning English, which is key to later academic success. ${ }^{20}$ However, as English-language hagwons are more expensive, lower-income families tend to send their children to less expensive institutions focused on art and recreation. The strong academic focus for young children is illustrated by a 2010 survey of mothers of children between the ages of three and six in Seoul and other large Asian cities (Tokyo, Beijing, Shanghai and Taipei). Korea stands out for its emphasis on having children begin academic subjects at an early age: Korean language (39\%), English (34\%) and mathematics $(32 \%)$. In the other Asian cities, the most popular activities for children's classes were swimming, gymnastics, drawing, crafts, dance and music classes (Child Research Net, 2010).

79. The exceptionally low level of public spending on ECEC in Korea and the high share of private outlays makes the quality of ECEC dependent on a household's income level, thus limiting the opportunities for low-income children. Consequently, children enter primary school with varying levels of education. While the drive to provide support for ECEC to all children aged three to five promotes higher enrolment and eases the burden on families, it does not create equal opportunities for high-quality educational opportunities, which would instead require other policies. First, increasing the capacity of public kindergartens would improve access for low-income families. As noted above, the 2010 revision of the kindergarten law allows kindergartens to be attached to primary or secondary schools. With falling enrolments, schools presumably will have empty classrooms that could be used for kindergartens. Moreover, it should be mandatory for new primary schools in urban areas to include kindergartens. Second, higher tuition subsidies for low-income families would improve their access to private kindergartens.

\section{Reducing the reliance on private tutoring: addressing the issue of hagwons}

80. Private tutoring appears to produce results; in the 2010 government survey cited above (Table 8), less than $4 \%$ of parents said that it is ineffective. Indeed, participation by students in the top $30 \%$ of their class was over $80 \%$ in 2010 , compared to less than $50 \%$ in the bottom $20 \%$ (Table 13 ). Moreover, outlays per student for the upper group are more than double those for the lower group. In short, participation in private tutoring appears to contribute to successful educational outcomes for parents able and willing to purchase such services for their children.

81. In addition, participation and spending on private tutoring are highly correlated with family income (Figure 14). Only 36\% of students from families with a monthly income of less than 1 million won participated in private tutoring, compared to $80 \%$ for those from families earning 3 to 4 million won. Similarly, the amount of outlays per student in private tutoring is four times higher for the middle-income group than those in the lowest-income group. For households with income over 6 million won per month, enrolment rates rise to nearly $90 \%$, while outlays per month reach around 450 thousand won (around $\$ 400$ ).

20. Only $9 \%$ of children began studying English due to their curiosity about the language. 
ECO/WKP(2013)59

Table 13. Participation and spending in private tutoring rises with academic performance

\begin{tabular}{c|ccc|ccc}
\hline $\begin{array}{c}\text { Student's } \\
\text { class ranking }\end{array}$ & \multicolumn{3}{|c|}{$\begin{array}{c}\text { Participation in private tutoring } \\
\text { (Per cent) }\end{array}$} & \multicolumn{2}{c}{ Spending per student $^{1}$} \\
\hline & 2009 & 2010 & Change $^{2}$ & 2009 & 2010 & Change $^{2}$ \\
\cline { 2 - 7 } Top 10\% & 87.0 & 85.3 & -1.7 & 319 & 317 & -0.6 \\
$11 \sim 30 \%$ & 84.9 & 83.9 & -1.0 & 283 & 282 & -0.4 \\
$31 \sim 60 \%$ & 75.3 & 73.8 & -1.5 & 232 & 233 & 0.4 \\
$61 \sim 80 \%$ & 60.7 & 59.8 & -0.9 & 184 & 182 & -1.1 \\
Bottom 20\% & 50.4 & 48.8 & -1.6 & 139 & 136 & -2.2 \\
Total & $\mathbf{7 5 . 0}$ & $\mathbf{7 3 . 6}$ & $\mathbf{- 1 . 4}$ & $\mathbf{2 4 2}$ & $\mathbf{2 4 0}$ & $\mathbf{- 0 . 8}$ \\
\hline
\end{tabular}

1. Monthly outlays on private tutoring per student (all students, including those not involved in such education) in thousand won. 2. In percentage points.

Source: Ministry of Education, Science and Technology (2011).

Figure 14. Household income and participation and spending on private tutoring in 2010
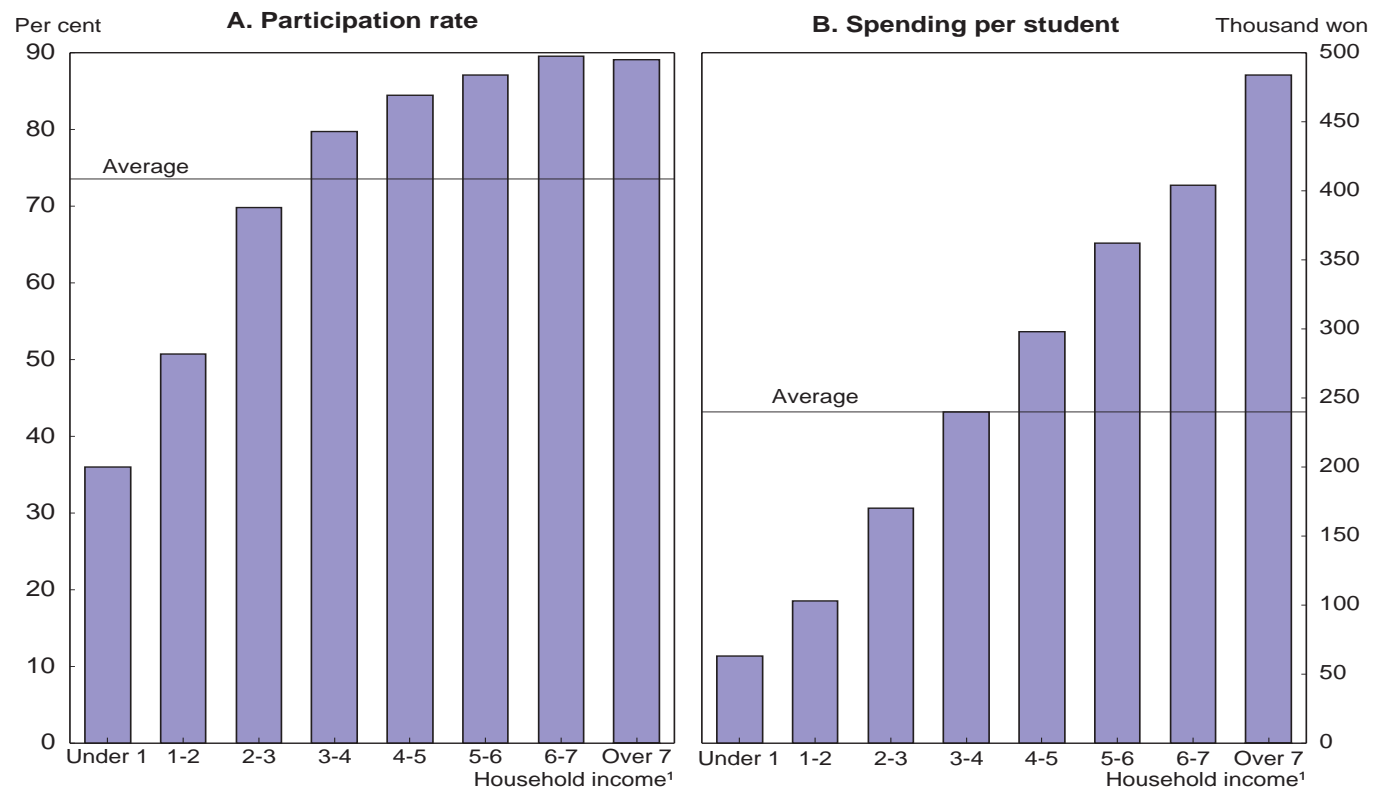

1. In million won per month.

Source: Ministry of Education, Science, and Technology (2011).

82. While Korea places a high value on egalitarianism, policies to promote equal opportunity are undermined by the heavy reliance on private tutoring to enter high-ranking universities, which has an inordinate impact on job prospects and future income (Kim and Lee, 2003). The higher participation and spending on private tutoring thus allows family income to determine access to higher education, creating cycles of poverty and wealth that endure over generations:

- The poorer a student's background, the more likely he or she is to attend college rather than university.

- The dropout rate from college ( $8 \%)$ is double that for university $(4 \%)$. 
- A student with a better socioeconomic background is more likely to enter a prestigious university and study a subject that he or she would like to. One study found that $16.9 \%$ of students from the upper-middle income class attended upper-level universities compared to only $5.8 \%$ for lowerclass students. For lower-level universities, the situation is reversed, with a much larger share of students from lower-income households (KEDI, 2006).

While the expansion of tertiary education opened the door to higher education for a larger share of the population, low-income students are concentrated in the low-ranking universities. It is important to address this source of inequality.

83. In addition to exacerbating socio-economic differences in educational results, and thereby creating and perpetuating inequality, there are a number of other disadvantages associated with private tutoring. First, it places heavy financial burdens on families, amounting to $10.7 \%$ of disposable income per child (Table 7). For a low-income family with half of the average household income, the cost would reach nearly $16 \%$ of disposable income for one child. Second, to the extent it duplicates school curricula, private tutoring absorbs resources that could be used more efficiently elsewhere. Third, even in Seoul where there is a 10 p.m. curfew for hagwons, private tutoring tends to unduly dominate children's lives and restrict their extra-curricular activities in ways that are detrimental to their well-rounded development. Fourth, private tutoring disrupts public education and undermines it by allowing some students to move ahead of their classmates, thus reducing their interest in school (Bray, 2009). Indeed, nearly half of students in private tutoring said that one of the reasons was to have access to advanced studies.

\section{Policies to reduce reliance on hagwons and other forms of private tutoring}

84. The $3.5 \%$ decline private tutoring expenses in 2010 , followed by a further $3.6 \%$ fall in 2011 , are encouraging. However, to achieve the government's goal of significantly reducing private tutoring, a number of policies are necessary, beginning with the criteria for university admission, including the CSAT. A major purpose of hagwons is to prepare students for the multiple-choice CSAT exam, which accounts for $70 \%$ of a student's high school ranking, compared to only $10 \%$ for the student's high school record (OECD, 2009). Reducing the importance of the CSAT in university admissions would thus reduce reliance on hagwons. Under the new "admissions officer" system to select university students, greater weight is given to other criteria, such as recommendations, essays and extra-curricular activities, as well as school grades, in order to reform the test score-based admission system. It will take time for the admissions officer system to gradually change students' mind sets over the long run. There is a need for caution, though, as a reliance on more subjective criteria opens up opportunities for favouritism and corruption, given the importance of social connections. One positive aspect of the reliance on multiple-choice exams is that it provides legitimacy to the university entrance process.

85. The 2010 government survey discussed above also asked parents which policies would reduce spending on private tutoring (Table 14). First, a number of responses focused on improving the quality of schools, as it would enable students to acquire sufficient education without participating in private tutoring. Specific areas for improvement included strengthening the creativity and character-building aspects of schools, improving the teaching of English, better supporting underachieving students and using teacher evaluation systems. Second, parents noted the importance of creating diverse schools, an objective the government is pursuing through its plan to establish 300 "autonomous" high schools. Third, strengthening vocational education and career guidance would reduce private tutoring. This is also supported by the second-ranked objective of "changing students' and parents' view of education and giving more access to information". Fourth, providing all-day kindergartens would reduce reliance on hagwons for child care.

86. The parent survey also suggested using tracking - separating students by ability levels - as a way of meeting the needs of individuals and reducing outlays for private tutoring. However, tracking, 
particularly at a young age, tends to increase inequality in educational outcomes (OECD, 2010a). Finally, there is support for stabilising hagwon fees. Given that hagwons are private enterprises providing heavily demanded services, government measures to limit their fees are likely to be difficult to implement.

\section{Making after-school lessons more accessible to low-income students}

87. Even with reforms, private tutoring will continue to play a significant role, making it important to provide its benefits more broadly and at lower cost. The government survey discussed above mentioned three alternatives. First, on-line education systems are a rapidly growing component of the private tutoring service industry in many countries (Ventura and Jang, 2010) and tend to be much less expensive. In Korea about one-third of students participating in private tutoring use Internet lessons, including those offered by hagwons, and the government's Cyber Home Learning. The government system, which has three million users, with 228 thousand visits per day, could be further expanded. The government estimates that it reduced private tutoring spending by 1.1 trillion won (5\% of actual spending) in 2011. Second, the public Educational Broadcast System, established in 1990, provides lectures to high school students preparing for the university admission exam. This system had 3.9 million users in 2011, with about 694 thousand visits per day, cutting private tutoring spending by another 816 billion won.

Table 14. Policies that would reduce spending on private tutoring

Five-point scale ${ }^{1}$

\begin{tabular}{clr}
\hline Rank & & \multicolumn{1}{c}{ Policy } \\
\hline 1 & Use tracking to separate students into classes based on their academic ability & 4.0 \\
2 & Changing students' and parents' view of education and giving more access to information & 3.9 \\
2 & Creating good and diverse schools & 3.9 \\
2 & Strengthening the creativity and character-building aspects of education & 3.9 \\
2 & Stabilising tuition fees of hagwons & 3.9 \\
6 & Strengthening the teaching of English in public schools & 3.8 \\
6 & Supporting underachieving students & 3.8 \\
8 & Using on-line education systems & 3.7 \\
8 & Teacher evaluation systems & 3.7 \\
8 & Disclosure of school information & 3.7 \\
11 & Revitalising after-school programmes & 3.6 \\
11 & Strengthening vocational education and career guidance & 3.6 \\
11 & Supporting customised education service using IPTV & 3.6 \\
14 & Moving students to different classrooms according to their achievement level & 3.5 \\
15 & during regular school hours & 3.4 \\
\hline
\end{tabular}

1. The government survey asked parents to rank policies that would reduce spending on private tutoring. Source: Ministry of Education, Science, and Technology (2011).

88. In addition, the after-school programmes offered at virtually all primary and secondary schools could be further expanded to reduce outlays on private tutoring. The number of students participating in such programmes (both free and paid) rose from 43\% when they were introduced in 2006 to $65 \%$ in 2011, with higher rates for low-income families and those in rural areas, who have less access to hagwons. Twothirds of the instruction is provided by school teachers, who offer lessons that could not be covered in regular classes (Kim, 2010). An OECD study found that after-school classes with a teacher can enhance equity, in contrast to such classes with teachers from the outside (OECD, 2011). Eight of the 16 metropolitan and provincial offices of education allow the programmes to be contracted out to for-profit 
organisations. Spending on private tutoring was reduced from an average of 3.5 million won to 3.0 million won for students participating in after-school lessons in schools.

\section{Reducing the burden of tertiary education}

89. The public-sector share of spending on tertiary education was only $26 \%$ in 2009 , well below the OECD average of $70 \%$ (Figure 2). Private institutions, which account for around three-quarters of students, depend primarily on tuition fees. Consequently, tuition fees at private universities were the third highest in the OECD area at \$9 366 (PPP exchange rates) in the 2008-09 academic year (Figure 15). Fees at the most expensive institutions were about double those at the least expensive. Although public university fees are lower at $\$ 5193$, they are still the third highest among OECD countries. At the same time, government scholarships and grants to students (6.0\% of public spending on education) and student loans $(5.4 \%)$ were well below the OECD averages of $11.4 \%$ and $8.8 \%$, respectively (OECD, 2011a). In total, public subsidies to households for tertiary education in the 2008-09 academic year amounted to $0.1 \%$ of GDP, only onethird of the OECD average of $0.3 \%$ and the fifth lowest in the OECD. Consequently, a student's socioeconomic background is significantly correlated with the quality of the tertiary institution that he or she attends. University tuition has become one of the most heated political issues in Korea. Student protests in 2011 coalesced around the slogan "half-price tuition". In June 2011, the ruling party proposed cutting tuition fees by $30 \%$ by 2014 . In 2012 , fees are to be reduced by $15 \%$ through 1.5 trillion won of government spending and by requiring universities to increase grants by 0.5 trillion won.

Figure 15. International comparison of university tuition fees ${ }^{1}$

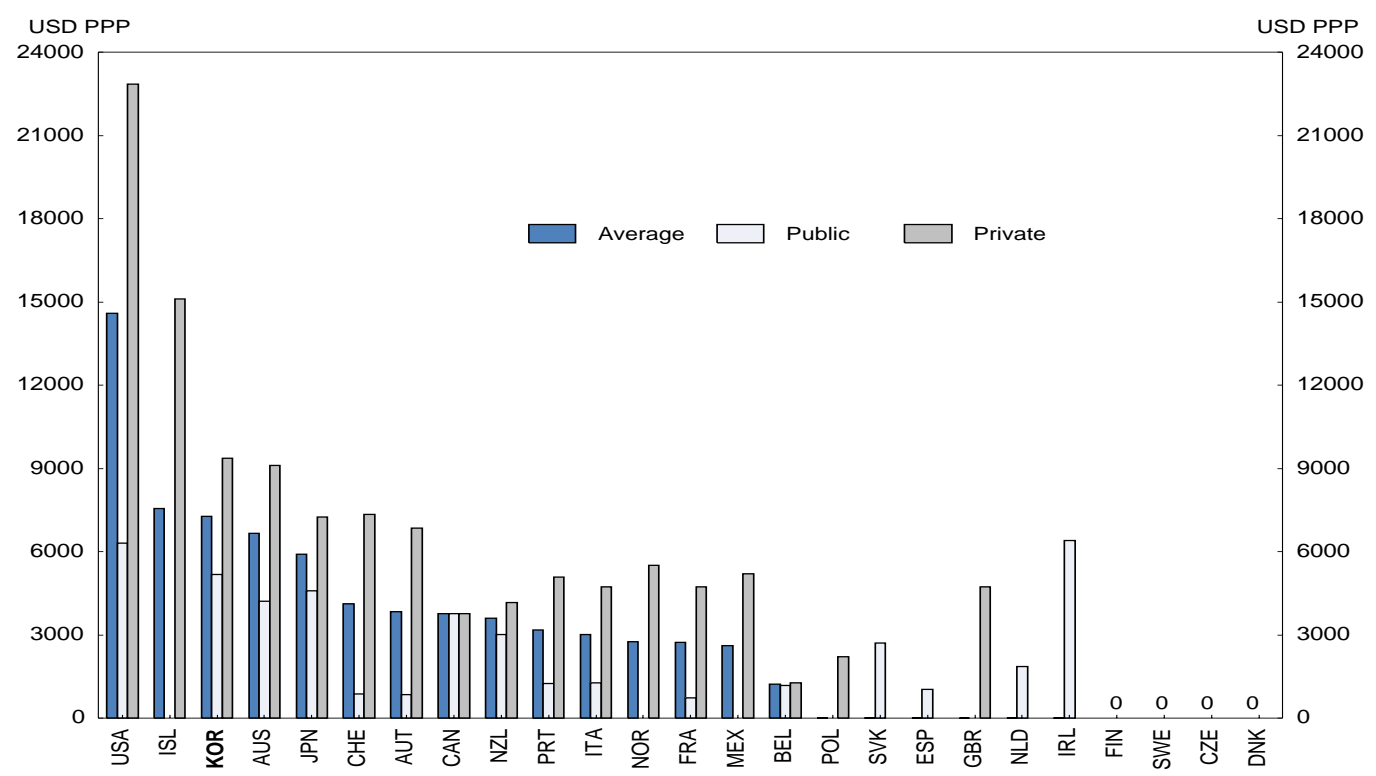

1. Full-time students at tertiary type A institutions in 2008-09. Tuition fees are not adjusted for fee waivers granted by institutions or for tax treatment of tuition fees.

Source: OECD (2012b), OECD Education at a Glance 2012.

90. The government has already taken several steps to address the tuition issue. First, the government put a ceiling on increases in university tuition beginning in 2011; the percentage increase in tuition cannot be more than 1.5 times higher than the average increase of the consumer price index during the previous three years. Second, it required universities to organise a tuition review committee that includes professors and students. Third, the government established the Korean Student Aid Foundation in 2009 to provide means-tested grants and to administer the major government-sponsored student loan schemes. The share of university students receiving scholarships because of their low-income background increased from $3.1 \%$ in 
2009 to $4.4 \%$ in 2011 . The amount per student, though, was less than one-half of the average tuition at a private university.

91. The 2012 reform of the scholarship programme to reduce the burden of tuition fees created two types of grants, boosting outlays from 335 billion won in 2011 to 1.5 trillion won. Type I grants are allocated to low-income students through universities. Students who qualify for the Basic Livelihood Security Programme, the basic welfare programme that covers $3 \%$ of the population, receive 4.5 million won (around \$4 000) per year. In addition, the rest of those in the bottom 10\% of the income distribution receive 2.25 million won. ${ }^{21}$ Type II grants allow universities to support students in the bottom $70 \%$ of the income distribution based on their self-help efforts. The 1.5 trillion won in total outlays are divided equally between Types I and II.

92. In addition, the government introduced in 2010 the "Study Now, Pay Later" programme of public loans for undergraduates who meet the grade requirement and are from households below the $70 \%$ income percentile. Repayment of the loan is contingent on post-graduation income, thus helping to overcome the aversion to debt. Meanwhile, the income criterion for the regular government-guaranteed loan scheme, which was introduced in 2005 on a means-tested basis, was abolished, making the loans available to all students who meet the grade criteria. This scheme imposes a fixed-repayment schedule. With the introduction of the income-contingent loan programme, the number of students receiving loans under the regular programme fell by more than one-third between the second semesters of 2009 and 2011, but the overall number receiving loans rose by $8 \%$ (Table 15). In contrast to scholarships, government loans cover a substantial share of tuition.

Table 15. Government-guaranteed loans for university tuition

In billion won in the second semester of academic year

\begin{tabular}{|c|c|c|c|c|c|c|c|c|}
\hline \multirow[b]{3}{*}{$\begin{array}{l}\text { Regular loan programme } \\
\text { Income-contingent loans } \\
\text { Total }\end{array}$} & \multicolumn{2}{|c|}{2009} & \multicolumn{2}{|c|}{2010} & \multicolumn{2}{|c|}{2011} & & \\
\hline & $\begin{array}{l}\text { Number } \\
\text { of } \\
\text { students }^{1}\end{array}$ & Amount & $\begin{array}{l}\text { Number } \\
\text { of } \\
\text { students }^{1}\end{array}$ & Amount & $\begin{array}{l}\text { Number } \\
\text { of } \\
\text { students }^{1}\end{array}$ & Amount & $\begin{array}{l}\text { Amount } \\
\text { per } \\
\text { student }^{2}\end{array}$ & $\begin{array}{l}\text { Share } \\
\text { of } \\
\text { tuition }^{3}\end{array}$ \\
\hline & $\begin{array}{l}331.5 \\
331.5\end{array}$ & 1201 & $\begin{array}{l}248.2 \\
117.7 \\
365.9\end{array}$ & $\begin{array}{c}885 \\
405 \\
1290\end{array}$ & $\begin{array}{l}209.9 \\
148.3 \\
358.1\end{array}$ & $\begin{array}{c}767 \\
499 \\
1265\end{array}$ & $\begin{array}{l}3.7 \\
3.4 \\
3.5\end{array}$ & $\begin{array}{l}88.2 \\
81.3 \\
85.3\end{array}$ \\
\hline
\end{tabular}

1. In thousands of students.

2. In million won.

3. In 2011. Tuition is calculated from the 2008 figure shown in OECD Education at a Glance, adjusted by the CPI index for 2011.

4. Introduced in $\mathbf{2 0 1 0}$ for students from low-income families. This programme is also referred to as "Study Now, Pay Later".

Source: Ministry of Education, Science and Technology.

93. While politically popular, half-price tuition would have a number of drawbacks. First, universally subsidising tuition fees could lead to even more students going to university, thereby exacerbating the problem of overemphasis on tertiary education and skill mismatches. Second, half-price tuition raises questions about value for money, as it would effectively subsidise low-quality institutions that should instead be restructured or closed. Third, subsidising the tuition fees for all students is less efficient and less equitable than targeting support on students from low-income households, who face larger hurdles in accessing tertiary education. Fourth, it could cost about 7 trillion won $\left(0.6 \%\right.$ of GDP). ${ }^{22}$

21. The amount falls to 1.35 million won for those in the second to bottom decile and to 0.9 million won for those in the third to bottom decile.

22. Given that a $15 \%$ reduction would cost 2 trillion won (Korea Herald, 23 June 2011), a 50\% tuition reduction would cost around 7 trillion won, which is about $0.6 \%$ of 2011 GDP. 
Experience in other countries suggests it is very difficult to move away from universal subsidisation of tuition once it is in place. Caution is thus warranted given the long-lasting financial consequences. The government has appropriately sought to reframe the issue as part of a wider reform of the tertiary sector.

94. The new income-contingent loan scheme, which is limited to the lower $70 \%$ of the income distribution, should be extended to all students, subject to their satisfactory academic progress. The government recently cut the interest rate on loans, exempted interest payments during military service and eased the grade point average requirement for eligibility. Such reforms should continue to increase access to the income-contingent loan programme. Making reimbursement dependent on post-graduation income is crucial. Otherwise, the loan take-up ratio would be limited by potential students' risk aversion. Moreover, some students may otherwise borrow less by taking a shorter, less costly course of study than is optimal. In addition, given the difficulties university graduates face in finding employment, reforms to increase the flexibility of outstanding fixed-repayment student loans would be helpful. At present, around 80000 students are delinquent in their repayments. Moreover, universities need to provide quality education for the scheme to be successful. Otherwise students will not be able to find a good job and earn enough money to pay back their loans. Finally, the government should consider whether the tax deductibility of tuition payments is the most equitable way to lighten the financial burden of tertiary education. Given that only half of the labour force pays income tax, and that many of them that do pay face only a $6 \%$ rate, tax benefits reduce the cost of tertiary education primarily for high-income families.

\section{Conclusion}

95. Implementing educational reform is challenging, given its central role in every country and the magnitude of what is at stake. In Korea, the high importance accorded to education and the politicisation of some of the key education issues make reform even more difficult. Between 2003 and 2007, education ministers served for an average of only eight months, hindering the launch of serious reform measures (Chang, 2009). Making reform happen depends on a number of factors. First, it is important to actively engage stakeholders - notably parents, teachers, students and school administrators - in formulating and implementing policy responses. In particular, teachers need reassurance that they will receive the tools needed to be successful. Second, it is necessary to clearly explain the underlying principles and aims of reform. Third, reform should be based on clear evidence. Given the complexity of the education system, there are no simple action plans that can deliver major improvements. Moreover, even with good policies, improved educational results usually take a long time to achieve, and clear evidence of the improvements even longer. Hence, all stakeholders ought to have realistic expectations about the possibility of achieving better education results. Nevertheless, upgrading the education system is crucial, as even small improvements can have significant positive impacts. Key elements of the comprehensive reform discussed above are summarised in Box 3. 
ECO/WKP(2013)59

\section{Box 3. Summary of recommendations to reform Korea's education system}

\section{Reforms to sustain growth}

\section{Early childhood education and care}

- $\quad$ Raise the proportion of children attending kindergarten by expanding tuition subsidies, especially for low-income children, and increasing the capacity of public kindergarten by including them in primary school buildings.

- Improve the quality of private childcare facilities by upgrading the accreditation process and making it mandatory and relaxing fee ceilings on private childcare, which impinge on quality.

- $\quad$ Upgrade the quality of teachers by increasing the requirements in ECEC.

- $\quad$ Gradually integrate childcare and kindergartens to improve quality, while achieving cost savings.

\section{Primary and secondary schools}

- Increase the autonomy of schools and promote closer co-operation between local governments and local educational authorities, with the eventual aim of merging them.

- Expand school choice to encourage schools to excel, while continuing to expand diversity in the type of high schools to promote competition and excellence.

- Develop vocational education by increasing the number of Meister schools and developing National Technical Qualifications (NTQ) that link education and the labour market.

\section{Tertiary education}

- Increase transparency, including at the department level, while promoting internationalisation by facilitating the entry of foreign students and tertiary institutions in Korea, to enhance competition.

- Develop vocational education by enhancing the role of colleges and linking them to a streamlined set of NTQs.

- Use the rankings, which designate the lower $15 \%$ of institutions, to improve management and foster restructuring; incorporate other national universities, in addition to Seoul National University, to promote their autonomy.

- $\quad$ Make an upgraded accreditation system effective, while easing regulations to promote innovation and diversity.

- Expand the role of universities in innovation by strengthening links between research institutes in government, business and academia, in part by promoting the labour mobility of researchers.

\section{Reforms to promote social cohesion}

- Enhance the access of disadvantaged children to high-quality ECEC by increasing tuition subsidies for lowincome children.

- $\quad$ Increase the capacity of public kindergartens by including them in primary schools.

- Develop the "admissions officer" system for universities to reduce the importance of the CSAT exam, thereby diminishing the role of hagwons.

- $\quad$ Reduce dependence on private tutoring, including hagwons, by improving the quality and diversity of secondary schools and strengthening vocational education and career guidance.

- Improve access to after-school tutoring by further expanding Internet and broadcast teaching systems and increasing the after-school programmes in schools.

- $\quad$ Expand student loans through the new programme that makes repayment contingent on income after graduation. 


\section{Bibliography}

Akabayashi, H. (2006), “Average Effects of School Choice on Educational Attainment: Evidence from Japanese High School Attendance Zones", mimeo.

Bae, S., H. Oh, H. Kim, C. Lee and B. Oh (2010), "The Impact of After-School Programs on Educational Quality and Private Tutoring Expenses", Asia Pacific Education Review, Vol. 11.

Baek, Y. and R. Jones (2005), "Sustaining High Growth Through Innovation: Reforming the R\&D and Education Systems in Korea", OECD Economics Department Working Papers, No. 470, OECD, Paris.

Bray, M. (2009), Confronting the Shadow Education System, International Institute for Educational Planning, UNESCO, Paris.

Chang (2009), "A cultural and Philosophical Perspective on Korea's Education Reform: A Critical way to Maintain Korea's Economic Momentum”, Academic Paper Series on Korea, Korea Economic Institute, Washington, DC.

Child Research Net (2010), 2010 Report on Children: Questionnaire Survey on Children's Daily Lives and Parent's Child-rearing in Five East Asian Cities.

Chung, B. (2002), "Korea's War on Private Tutoring", Paper presented at The Second International Forum on Education Reform, 2-5 September, Bangkok.

Jones, R. and T. Yokoyama (2005), "Getting the Most Out of Public-Sector Decentralisation in Korea", OECD Economics Department Working Papers, No. 468, OECD, Paris.

Kim, M. (2003), "Teaching and Learning in Korean Classrooms: The Crisis and the New Approach", Asia Pacific Education Review, Vol. 4.

Kim, S. and J. Lee (2003), "The Secondary School Equalization Policy in South Korea”, mimeo.

Kim, J. (2007), "Child Care Support Programs for Double Income Families in Korea", in Generational Change and Social Policy Challenges Australia and South Korea, edited by R. Phillips, Sydney University Press.

Kim, H. (2010), "The Achievement and Development of After-school Activities", Early Childhood Care and Education in Korea, Vol IX, Korea Educational Development Institute, Seoul.

Koh, Y., S. Kim, C. Kim, Y. Lee, J. Kim, S. Lee and Y. Kim (2010), "Social Policy", in The Korean Economy: Six Decades of Growth and Development, edited by I. SaKong and Y. Koh, Korea Development Institute.

Korea Educational Development Institute (2006), OECD Thematic Review of Tertiary Education: Country Background Report for Korea, KEDI, Seoul.

Korea Educational Development Institute (2010), Brief Statistics on Korean Education, KEDI, Seoul.

Korea Research Institute for Vocational Education and Training (KRIVET) (2007), Report on the Employment, Education and Training of University Graduates, KRIVET, Seoul.

Lee, J. and Y. Lee (2009), "A Study on the Current Status of Non-enrolled Children in Kindergartens and Childcare Facilities", Research Project-03, Korea Institute of Child Care and Education, Seoul.

Lee, Y., M. Moon, M. Kim and S. Yang (2009), "A Survey on the Current Status of Hakwons (private academies) for Young Children in Korea", Research Project-05, Korea Institute of Child Care and Education, Seoul. 
Lee, Y. (2010), "Views on Education and Achievement: Finland's Story of Success and South Korea's Story of Decline", KEDI Journal of Educational Policy, Vol. 7, No. 2.

McKinsey \& Company (2010), How the World's Most Improved School Systems Keep Getting Better.

McNeill, D. (2011), "After Decades of Building Colleges, South Korea Faces a Lack of Students", The Chronicle of Higher Education, 27 November.

Ministry of Education (2000), Report on Private Tutoring, Seoul.

Ministry of Education, Science and Technology (MEST) (2009), Becoming a S\&T Powerhouse through the "577 Initiative", Seoul.

Ministry of Education, Science and Technology (MEST) (2010), Secrets of an Educational Powerhouse, Seoul.

Ministry of Education, Science and Technology (MEST) (2011), Analysis of the Results of the 2010 Survey on Private Education Costs, Seoul (in Korean).

Moon, M. (2010), "Enhancing the Quality of Full-day Kindergarten Education in Korea”, International Journal of Child Care and Education Policy, Vol. 4, No. 2.

Na, J. and M. Moon (2003), The OECD Thematic Review of Early Childhood Education and Care Policy: Background Report for the Republic of Korea, Korean Educational Development Unit, Seoul.

Na, J. (2010), Early Childhood Education and Care Policy in Korea, Understanding Korean Educational Policy, Vol. 9, Korean Educational Development Institute, Seoul.

OECD (2004), Early Childhood Education and Care Policy in the Republic of Korea: OECD Country Note, OECD, Paris.

OECD (2006), Starting Strong II, OECD, Paris.

OECD (2007), Family Database, website.

OECD (2008a), OECD Economic Survey of Korea, OECD, Paris.

OECD (2008b), OECD Education at a Glance 2008, OECD, Paris.

OECD (2009), OECD Reviews of Tertiary Education: Korea, OECD, Paris.

OECD (2010a), Education Today, OECD, Paris.

OECD (2010b), Learning for Jobs, OECD, Paris.

OECD (2010c), OECD Economic Survey of Korea, OECD, Paris.

OECD (2010d), PISA 2009 Results: What Students Know and Can Do, Volume I, OECD, Paris.

OECD (2010e), PISA 2009 Results: Overcoming Social Background, Volume II, OECD, Paris.

OECD (2011a), A Framework for Growth and Social Cohesion in Korea, OECD, Paris.

OECD (2011b), Doing Better for Families, OECD, Paris.

OECD (2011c), OECD Education at a Glance 2011, OECD, Paris.

OECD (2011d), OECD Science, Technology and Industry Scoreboard, 2011, OECD, Paris.

OECD (2011e), PISA in Focus, No. 3, OECD, Paris.

OECD (2012a), OECD Economic Survey of Korea, OECD, Paris.

OECD (2012b), OECD Education at a Glance 2012, OECD, Paris. 
Park, D., S. Baek, M. Chang, D. Choi and M. Kim (2010), “The Demand for Vocational High School Graduates and Strategies to Improve Educational Capacity", Korea Research Institute for Vocational Education and Training, Seoul.

Rhee, O. (2007a), "Childcare policy in Korea: Current Status and Major Issues", International Journal of Child Care and Education Policy, Vol. 1, No. 1.

Rhee, B. (2007b), "Incorporation of National Universities in Korea: Dynamic Forces, Key Features, and Challenges", Asia Pacific Journal of Education, Vol. 27.

Rhee, O., E. Kim, N. Shin and M. Moon (2008), "Developing Models to Integrate Early Childhood Education and Childcare in Korea", International Journal of Child Care and Education Policy, Vol. 2, No. 1 .

Santiago, P., K. Tremblay, E. Basri and E. Arnal (2008), Tertiary Education for the Knowledge Society, Vol. 1, OECD, Paris.

Sorensen, C. (1994), "Success and Education in South Korea", Comparative Education, Vol. 38, No. 1.

Suh, M., E. Kim, H. Chang and S. Park (2008), "A Study on Childcare Support for Working Women", Entrusted Research Projects-02, Korea Institute of Child Care and Education, Seoul.

Suh, M., H. Shin and S. Song (2009), "A Study on the Effectiveness of Childcare Accreditation", Expedited Research Projects-02, Korea Institute of Child Care and Education, Seoul.

Suh, M. and E. Kim (2010), Early Childhood Education and Care Policy in Korea, Korea Institute of Child Care and Education, Seoul.

Sutherland, D. and R. Price (2007), "Linkages Between Performance and Institutions in the Primary and Secondary Education Sector", OECD Economics Department Working Papers, No. 558, OECD, Paris.

Ventura, A. and S. Jang (2010), "Private Tutoring through the Internet: Globalization and Offshoring", Asia Pacific Education Review, Vol. 11.

World Bank (1993), The East Asian Miracle: Economic Growth and Public Policy, Oxford University Press, Oxford.

Yonezawa, A. and T. Kim (2008), "The Future of Higher Education in the Context of a Shrinking Student Population: Policy Challenges for Japan and Korea", Higher Education to 2030, Vol. 1: Demography, OECD, Paris.

Yoo, H., M. Lee, M. Chang, E. Kim, E. Kim and S. Song (2008), "Developing Ways of Cooperation and Integration of Kindergartens and Child Care Centers", Research Project-08, Korea Institute of Child Care and Education, Seoul.

Yoshida, A., K. Kogure and K. Ushijima (2009), "School Choice and Student Sorting: Evidence from Adachi City in Japan”, The Japanese Economic Review, Vol. 60.

Yun, E. (2009), "Places for Educating and Caring for Young Children in Korea: Where are our Children Edu-cared?", Child Research Net. 


\section{WORKING PAPERS}

The full series of Economics Department Working Papers can be consulted at www.oecd.org/eco/workingpapers/

1066. Belgium: enhancing the cost efficiency and flexibility of the health sector to adjust to population ageing

(June 2013) by Stéphane Sorbe

1065. Italy and the euro area crisis: securing fiscal sustainability and financial stability

(June 2013) by Oliver Denk

1064. Policy implementation in Italy: legislation, public administration and the rule of law (June 2013) by Paul O’Brien

1063. Greening growth in Luxembourg

(June 2013) by Nicola Brandt

Vers une croissance plus verte en Luxembourg

(juin 2013) par Nicola Brandt

1062. The post-crisis narrowing of international imbalances - cyclical or durable?

(June 2013) by Patrice Ollivaud and Cyrille Schwellnus

1061. Restructuring welfare spending in Slovenia

(June 2013) by Rafał Kierzenkowski

1060. The economics of civil justice: new cross-country data and empirics

by G. Palumbo; G. Giupponi; L. Nunziata and J. Mora-Sanguinetti (forthcoming)

1059. Banks' restructuring and smooth deleveraging of the private sector in Slovenia

(June 2013) by Olena Havrylchyk

1058. Assessing the efficiency of welfare spending in Slovenia with data envelopment analysis

(June 2013) by Matevz Hribernik and Rafał Kierzenkowski

1057. Policy determinants of school outcomes under model uncertainty: evidence from South Africa (June 2013) by Thomas Laurent, Fabrice Murtin, Geoff Barnard, Dean Janse van Rensburg, Vijay Reddy, George Frempong and Lolita Winnaar

1056. Improving education quality in South Africa (June 2013) by Fabrice Murtin

1055. The $90 \%$ public debt threshold: the rise and fall of a stylised fact (June 2013) by Balázs Égert

1054. Challenges to sustain Poland's growth model

(June 2013) by Balázs Égert and Rafał Kierzenkowski

1053. Reforming agriculture and promoting Japan's integration in the world economy

(May 2013) by Randall S. Jones and Shingo Kimura

1052. Inequality and poverty in the United States: public policies for inclusive growth 
(May 2013) by Oliver Denk, Robert Hagemann, Patrick Lenain and Valentin Somma

1051. Fiscal federalism and its impact on economic activity, public investment and the performance of educational systems

(May 2013) by Hansjörg Blöchliger, Balázs Égert and Kaja Fredriksen

1050. Restoring Japan's fiscal sustainability

(May 2013) by Randall S. Jones and Satoshi Urasawa

1049. Measuring total factor productivity at the firm level using OECD-ORBIS

(May 2013) by Peter Gal

1048. A projection method for public health and long-term care expenditures

(June 2013) by Christine de la Maisonneuve and Joaquim Oliveira Martins

1047. $R \& D$, patenting and growth: the role of public policy

(May 2013) by Ben Westmore

1046. Knowledge-based capital, innovation and resource allocation

(May 2013) by Dan Andrews and Chiara Criscuolo

1045. Reforms for a Cleaner, Healthier Environment in China

(April 2013) by Sam Hill

1044. Making the tax system less distortive in Switzerland

(April 2013) by Andrés Fuentes

1043. The determinants of informality in Mexico's states

(April 2013) by Sean M. Dougherty and Octavio Escobar

1042. Legal reform, contract enforcement and firm size in Mexico

(April 2013) by Sean M. Dougherty

1041. Improving the economic situation of young people in France

(April 2013) by Hervé Boulhol

Améliorer la situation économique des jeunes en France

(avril 2013) par Hervé Boulhol

1040. Improving employment prospects for young workers in Spain

(April 2013) by Anita Wölfl

1039. Youth labour market performance in Spain and its determinants - a micro-level perspective (April 2013) by Juan J. Dolado, Marcel Jansen, Florentino Felgueroso, Andres Fuentes and Anita Wölfl

1038. The efficiency and equity of the tax and transfer system in France

(April 2013) by Balázs Égert

Efficacité et équité du système de prélèvements et de transferts en France

(avril 2013) par Balázs Égert 